Marquette University

e-Publications@Marquette

$5-1-2013$

Chitosan-cellulose Composite Materials: Preparation, Characterization and Application for Removal of Microcystin

Chieu D. Tran

Marquette University, chieu.tran@marquette.edu

Simon Duri

Marquette University, simon.duri@marquette.edu

Ambra Delneri

University of Nova Gorica

Mladen Franko

University of Nova Gorica

Accepted version. Journal of Hazardous Materials, Vol. 252-253 (May 2013): 355-366. DOI. (C) 2013 Elsevier. Used with permission. 


\title{
Chitosan-Cellulose Composite Materials: Preparation, Characterization and Application for Removal of Microcystin
}

\author{
Chieu D. Tran \\ Department of Chemistry, Marquette University \\ Milwaukee, WI \\ Simon Duri \\ Department of Chemistry, Marquette University \\ Milwaukee, WI \\ Ambra Delneri \\ Department of Environmental and Physical Chemistry \\ Nova Gorica University \\ Nova Gorica, Slovenia \\ Mladen Franko \\ Department of Environmental and Physical Chemistry \\ Nova Gorica University \\ Nova Gorica, Slovenia
}




\begin{abstract}
We developed a simple and one-step method to prepare biocompatible composites from cellulose (CEL) and chitosan (CS). $\left[\mathrm{BMIm}{ }^{+} \mathrm{Cl}^{-}\right]$, an ionic liquid (IL), was used as a green solvent to dissolve and prepare the $[C E L+C S]$ composites. Since majority ( $>88 \%$ ) of IL used was recovered for reuse by distilling the aqueous washings of [CEL+CS], the method is recyclable. XRD, FTIR, NIR, ${ }^{13} \mathrm{C}$ CP-MAS-NMR and SEM were used to monitor the dissolution and to characterize the composites. The composite was found to have combined advantages of their components: superior mechanical strength (from CEL) and excellent adsorption capability for microcystin-LR, a deadly toxin produced by cyanobacteria (from CS). Specifically, the mechanical strength of the composites increased with CEL loading; e.g., up to $5 \mathrm{X}$ increase in tensile strength was achieved by adding $80 \%$ of CEL into CS. Kinetic results of adsorption confirm that unique properties of CS remain intact in the composite, i.e., it is not only a very good adsorbent for microcystin but also is better than all other available adsorbents. For example, it can adsorb 4X times more microcystin than the best reported adsorbent. Importantly, the microcystin adsorbed can be quantitatively desorbed to enable the composite to be reused with similar adsorption efficiency.
\end{abstract}

Keywords: Cellulose, Chitosan, Ionic Liquid, Green Chemisty, Cyanotoxins, Microcystins

\title{
1. Introduction
}

Microcystin LR, produced by cyanobacteria, is one of the most deadly toxins present in drinking water [1-4]. At least 40 species of cyanobacteria release toxic cyanotoxins into water during algal blooms. Microcystins (MCs) are the most prevalent class of cyanotoxins. The MCs are very soluble in water and consist of over 80 reported variants; however, four MCs (LR, RR, LA, and YR (See Scheme 1 for structures) are of special concern to the Environmental Protection Agency (EPA) and are on EPA Contaminant Candidate List III. The World Health Organization (WHO) has set a provisional drinking water guideline of $1 \mu \mathrm{g} / \mathrm{L}$ for MC-LR. The toxicity of MCs is due to their strong binding and inhibition of protein phosphatases. MCs are also known to promote the growth of tumors; have a genotoxic effect as well as strong mutagenicity [1-4].

Journal of Hazardous Materials, Vol. 252-253 (May 2013): pg. 355-366. DOI. This article is (C) Elsevier and permission has been granted for this version to appear in e-Publications@Marquette. Elsevier does not grant permission for this article to be further copied/distributed or hosted elsewhere without the express permission from Elsevier 


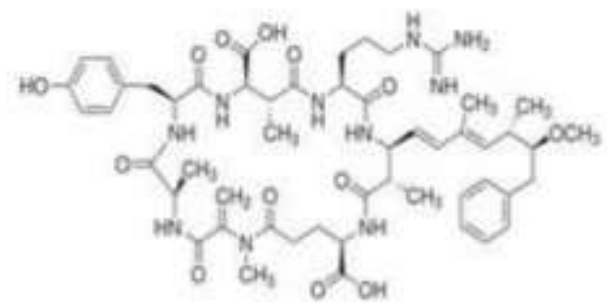

Microcystin LR

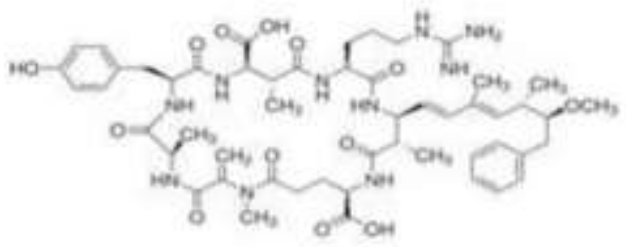

Microcystin YR

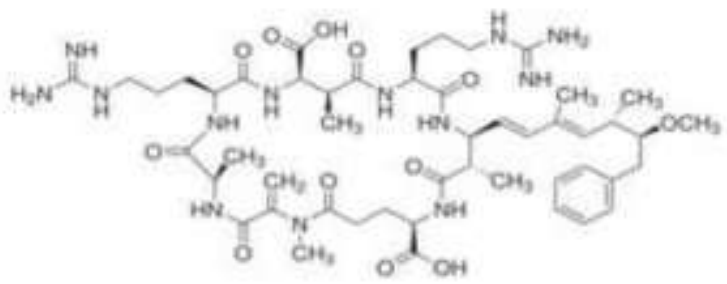

Microcystin RR

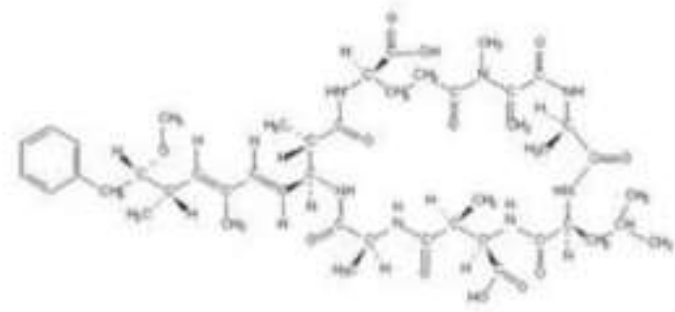

Microcystin LA

Scheme 1 Structure of microcystins (Note: nomenclature of the MCs is based on the amino acid substituents present, eg., L for leucine; R, arginine; $Y$, tyrosine; and $A$, alanine.)

The presence of toxic cyanobacterial blooms in drinking water reservoirs may represent serious health risks for the human population. Considerable efforts have, therefore, been made to develop removal methods. Limited success has been made by use of such adsorbents as activated carbon, oxidation by ozone and chlorine dioxide, $\mathrm{TiO}_{2}$ photocatalysis and ultrasonic irradiation [1-4]. Since these techniques cannot effectively remove the toxins in water, it is of particular importance that an effective removal technique based on the use of a biocompatible material be developed.

Chitosan (CS) is a linear amino polysaccharide, obtained by $\mathrm{N}$ deacetylation of chitin, and chitin, which is found in the exoskeletons of crustaceans (e.g., crabs and shrimp), is the second most abundant naturally occurring polysaccharide [5-8]. CS has been a subject of intense studies for many years [9-24]. The popularity stems from the fact that it is biodegradable, biocompatible, and possesses unique structure and properties which have been successfully exploited in many applications including hemostasis, wound healing, bactericide 
and fungicide, drug delivery and adsorbent for organic and inorganic pollutants [9-29]. Of particular interest are reports that CS, when modified with fly ash or immobilized on clay, can adsorb and remove algae such as Chlorella Pyrenoidosa or Microcystis Aeruginosa in water [30-35]. Unfortunately, in spite of its potentials, there are drawbacks which severely limit applications of CS. For example similar to cellulose (CEL), the most abundant substance on earth, in CS, a network of intra- and inter-hydrogen bonds enables it to adopt an ordered structure [6-8]. While such structure is responsible for CS to have aforementioned properties and CEL to have superior mechanical strength, it also makes them insoluble in most solvents [6-8]. As a consequence, high temperature and strong exotic solvents such as methylmorpholine-N-oxide, dimethylthexylsilyl chloride or $\mathrm{LiCl}$ in dimethylacetamide (DMAc) are needed to dissolve CEL whereas an acid such as acetic acid is required to protonate amino groups of CS to facilitate its dissolution in water [6-29]. These methods are undesirable because they are based on the use of corrosive and volatile solvents, require high temperature and suffer from side reactions and impurities which may lead to changes in structure and properties of the polysaccharides. More importantly, it is not possible to use a single solvent or system of solvents to dissolve both CEL and CS. Furthermore, CS is known to swell in water which leads to structural weakening in wet environments [6-21]. To increase the structural strength of CS products, attempts have been made to covalently bind or graft CS onto man-made polymers or clays to strengthen its structure [9-29]. Such modification is not desirable because it may inadvertently alter CS properties, making it not biocompatible and toxic and lessening or removing its unique properties. A new method which can effectively dissolve both CS and CEL not at high temperature and not by corrosive and volatile solvents but rather by recyclable "green" solvent is particularly needed. This is because such method would facilitate preparation of [CEL+CS] composite material which is not only biocompatible but also has combined properties of its components, namely mechanical strength (from CEL) and hemostasis, wound healing, bactericide, drug delivery and pollutant removal (from CS). Such demand makes recent report on ability of a simple ionic liquid, butyl methylimmidazolium chloride to dissolve up to $10 \%(\mathrm{w} / \mathrm{w})$ of CEL, particularly important [36].

Journal of Hazardous Materials, Vol. 252-253 (May 2013): pg. 355-366. DOI. This article is (C) Elsevier and permission has been granted for this version to appear in e-Publications@Marquette. Elsevier does not grant permission for this article to be further copied/distributed or hosted elsewhere without the express permission from Elsevier. 
Butyl methylimmidazolium chloride $\left(\left[\mathrm{BMIm}^{+} \mathrm{Cl}^{-}\right]\right)$belongs to a group of compounds known as ionic liquids (ILs). ILs are organic salts that are liquid at room temperature [37-40]. They have unique chemical and physical properties, including being air and moisture stable, a high solubization power, and virtually no vapor pressure [3740]. Because of these properties, they can serve as a "GREEN." recyclable alternative to the volatile organic compounds that are traditionally used as industrial solvents [37-40]. Due to their advantages, ILs have been used for applications which are not possible with other chemicals. For example, as described above, IL such as $\left[\mathrm{BMIm}{ }^{+} \mathrm{Cl}^{-}\right.$] can dissolve up to $10 \%(\mathrm{w} / \mathrm{w})$ of CEL. This discovery is of particular significance as it makes it possible for the first time that CEL can be dissolved, regenerated and chemically modified by use of a simple and green solvent which has high solubility power and low toxicity. Recently, it was found that $\left[\mathrm{BMIm}{ }^{+} \mathrm{Cl}^{-}\right]$can also dissolve CS as well [40].

The information presented is indeed provocative and clearly indicate that it is possible to develop a novel and green method to prepare novel polysaccharide composite materials for effective adsorption and removal of MCs. Such considerations prompted us to initiate this study which aims to hasten the breakthrough by systematically and revolutionarily exploit advantages of $\mathrm{IL}$, a green solvent, to develop a novel, simple, pollution-free and recyclable method to dissolve both CEL and CS, without using any harmful, volatile organic solvents and/or strong acid and base, for the preparation of polysaccharide ecocomposite materials containing CEL and CS, and to demonstrate that these materials are not only fully biocompatible but also superior to currently available materials for removal of MCs. The results of our initial investigation are reported herein.

\section{Materials and Methods}

\section{Chemicals}

Microcrystalline CEL (Avicel, DP 300 [41]), amorphous CEL and chitosan ( $M W \approx 310-375 \mathrm{kDa}, 75 \%$ degree of deacetylation, SigmaAldrich), microcystin-LR (Enzo Life Sciences) were used as received. 1-

Journal of Hazardous Materials, Vol. 252-253 (May 2013): pg. 355-366. DOI. This article is (C) Elsevier and permission has been granted for this version to appear in e-Publications@Marquette. Elsevier does not grant permission for this article to be further copied/distributed or hosted elsewhere without the express permission from Elsevier. 
methylimidazole and 1-chlorobutane (Alfa Aesar) were further purified by distillation. [BMIm ${ }^{+} \mathrm{Cl}^{-}$] was synthesized from 1-chlorobutane and 1 -methylimidazole using method previously reported [42, 43]. This IL is known to be hygroscopic and because any water presence is known to decrease its ability to dissolve polysaccharides [44], the IL was dried under vacuum at $70^{\circ} \mathrm{C}$ overnight before use.

\section{Instruments}

UV-visible spectra were measured on a Perkin Elmer Lambda 35 UV/VIS spectrometer. NIR spectra were taken on a home-built NIR spectrometer based on an acoustooptic tunable filter. Information on this NIR spectrometer was described in detail in our previous papers $[45,46]$. Normally, each spectrum was an average of 30 spectra taken at $1-\mathrm{nm}$ intervals from 1450 to $2450 \mathrm{~nm}$. FTIR spectra were measured on a PerkinElmer 100 spectrometer at $2 \mathrm{~cm}^{-1}$ resolution with either $\mathrm{KBr}$ or by a ZnSe single reflection ATR accessory (Pike Miracle ATR). Each spectrum was an average of 64 spectra. X-ray diffraction (XRD) measurements were taken on a Rigaku MiniFlex II diffractometer utilizing the $\mathrm{Ni}$ filtered $\mathrm{Cu} \mathrm{Ka}$ radiation (1.54059 $\AA$ ). The voltage and current of the X-ray tube were $30 \mathrm{kV}$ and $15 \mathrm{~mA}$ respectively. The samples were measured within the $2 \theta$ angle range from 2.0 to $40.0^{\circ}$. The scan rate was $5^{\circ}$ per minute. Data processing procedures were performed with the Jade 8 program package [47]. Scanning electron microscopic images of surface and cross section of the polysaccharide composite materials were taken under vacuum with an accelerated voltage of $3 \mathrm{kV}$ using Hitachi 54800 scanning electron microscope (SEM). Tensile strength measurements were performed on an Instron 5500R Tensile Tester.

\section{Preparation of CEL, CS and [CEL+CS] composite films}

Scheme 2 summarizes procedure used to dissolve and to regenerate films of $\mathrm{CEL}$ and/or CS with $\left[\mathrm{BMIm}^{+} \mathrm{Cl}^{-}\right]$as solvent. Specifically, CEL and/or CS were dissolved in $\left[\mathrm{BMIm}^{+} \mathrm{Cl}^{-}\right]$under argon and magnetic stirring at $100-110{ }^{\circ} \mathrm{C}$. All polysaccharides were added in portions of approximately $1 \mathrm{wt} \%$ of the IL. Succeeding portions were only added after the previous addition had completely dissolved until the desired concentration has been reached. For composite films,

Journal of Hazardous Materials, Vol. 252-253 (May 2013): pg. 355-366. DOI. This article is (C) Elsevier and permission has been granted for this version to appear in e-Publications@Marquette. Elsevier does not grant permission for this article to be further copied/distributed or hosted elsewhere without the express permission from Elsevier. 
the components were dissolved one after the other, with CEL being dissolved first. Using this procedure, solutions of CEL (containing up to $10 \% \mathrm{w} / \mathrm{w}$ (of IL)), CS (up to $4 \% \mathrm{w} / \mathrm{w}$ ) and composite solutions containing CEL and CS in various proportions were prepared in about 6-8 hours.

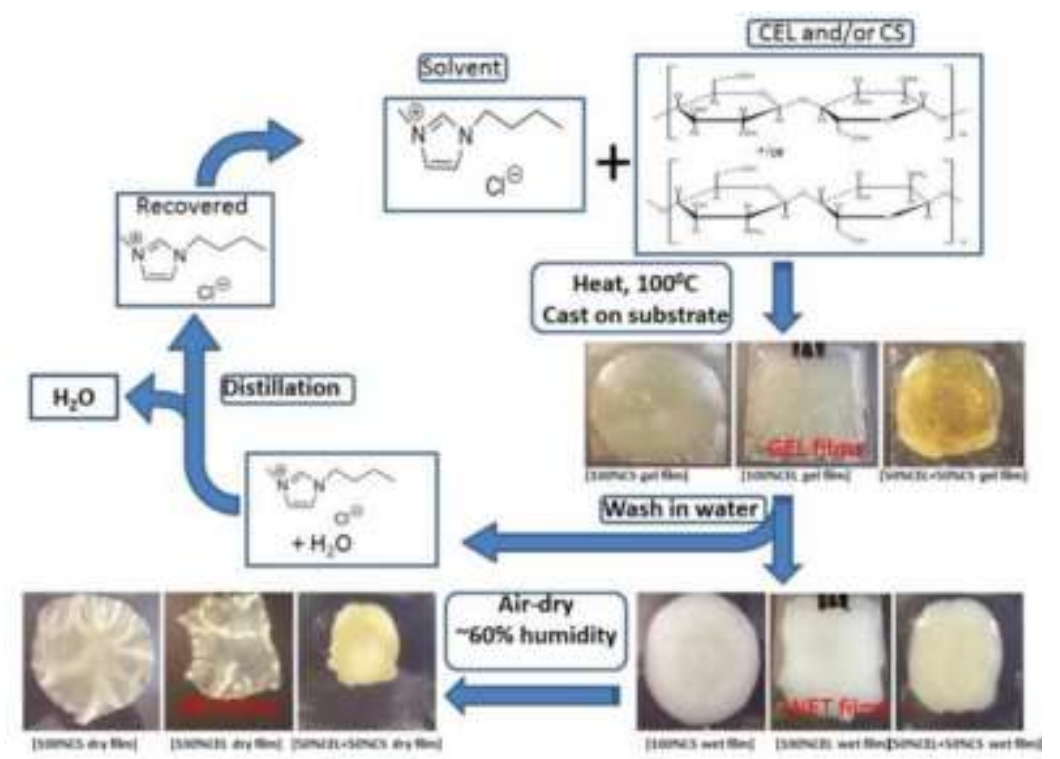

Scheme 2 Procedure used to prepare CEL, CS and [CEL+CS] composite materials.

Upon complete dissolution, the homogeneous solutions of the polysaccharides in $\left[\mathrm{BMIm}{ }^{+} \mathrm{Cl}^{-}\right.$] were cast on glass slides or Mylar sheets using a RDS stainless steel coating rod with appropriate size (RDS Specialties, Webster, NY) to produce thin films with different compositions and concentrations of CEL and CS. They were then kept at room temperature for 24 hours to allow the solutions to undergo gelation (henceforth referred as Gel Films).

In addition to the polysaccharides, the Gel Films also contained $\left[\mathrm{BMIm}{ }^{+} \mathrm{Cl}^{-}\right]$. The IL was removed from the films by washing the films in water for 3 days to yield "[BMIm $\left.{ }^{+} \mathrm{Cl}^{-}\right]$-free" films (i.e., Wet Films). During this period, the washing water was constantly replaced with fresh water to maximize the removal of the IL. The $\left[\mathrm{BMIm}^{+} \mathrm{Cl}^{-}\right]$used was recovered from the washed aqueous solution by distillation. Finally, Dried Films were obtained when the Wet Films are allowed to dry. Drying of the Wet Films was carried out at room temperature in a chamber with humidity controlled at $60 \%$. Drying time was found to 
NOT THE PUBLISHED VERSION; this is the author's final, peer-reviewed manuscript. The published version may be accessed by following the link in the citation at the bottom of the page.

be dependent on thickness of the films but generally was in range of 2-3 days.

Detailed information on measurements of swelling, adsorption and desorption can be found in the Supplementary Data

\section{Results and Discussion}

\subsection{Synthesis and Characterization of [CEL+CS] Composites}

Images of CEL, CS and [CEL+CS] composite materials during various stages of preparation are presented in Scheme 2. Specifically, images of films of one-component (CEL or CS) and two component [CEL+CS] casted right after the polysaccharides were dissolved in $\left[\mathrm{BMIm}^{+} \mathrm{Cl}^{-}\right.$], i.e., Gel Film, are shown in top center-left of the Scheme. After soaking in water for 3 days, $\left[\mathrm{BMIm}{ }^{+} \mathrm{Cl}^{-}\right]$was removed from the gel film to yield corresponding Wet Films. Finally, Dried Films were obtained when the wet film was allowed to dry at room temperature.

$\mathrm{XRD}, \mathrm{FTIR}, \mathrm{NIR}$ and ${ }^{13} \mathrm{C}$ Cross polarization-magic angle spinning NMR (CP-MAS-NMR) were used to follow and confirm the dissolution process and to characterize the films. Specifically, dissolution of CEL and $\mathrm{CS}$ in $\left[\mathrm{BMIm}{ }^{+} \mathrm{Cl}^{-}\right.$] was confirmed by XRD technique. Shown in Figure $1 A$ are XRD spectra of microcrystalline CEL (pink curve), the CEL one-component Gel Film (orange curve), the corresponding Dried Film (green curve) as well as that of $\left[\mathrm{BMIm}^{+} \mathrm{Cl}^{-}\right]$(blue curve) for reference. As illustrated, microscrystalline CEL exhibits diffraction peaks at $2 \theta=14.7^{\circ}$ and $16.3^{\circ}, 22.5^{\circ}$ and $34.6^{\circ}$ for (101), (002) and (040) plane, respectively. These bands disappeared completely when the powder polysaccharide was dissolved in $\left[\mathrm{BMIm}^{+} \mathrm{Cl}^{-}\right]$. The disappearance of these bands together with the similarity between the spectrum of liquid $\left[\mathrm{BMIm}^{+} \mathrm{Cl}^{-}\right.$] and that of the Gel Film clearly indicate that $\left[\mathrm{BMIm}{ }^{+} \mathrm{Cl}^{-}\right]$completely dissolved the polysaccharide. Similar results were also found for CS (Figure 1B), namely, the fact that diffraction bands of the CS powder disappeared when they were dissolved in $\left[\mathrm{BMIm}^{+} \mathrm{Cl}^{-}\right]$, clearly indicate that the $\left[\mathrm{BMIm}{ }^{+} \mathrm{Cl}^{-}\right]$also completely dissolved this polysaccharide. Similar results were also

Journal of Hazardous Materials, Vol. 252-253 (May 2013): pg. 355-366. DOI. This article is (C) Elsevier and permission has been granted for this version to appear in e-Publications@Marquette. Elsevier does not grant permission for this article to be further copied/distributed or hosted elsewhere without the express permission from Elsevier. 
obtained (Fig 1C) for two-component composite films containing $[C E L+C S]$ of $10: 3$.

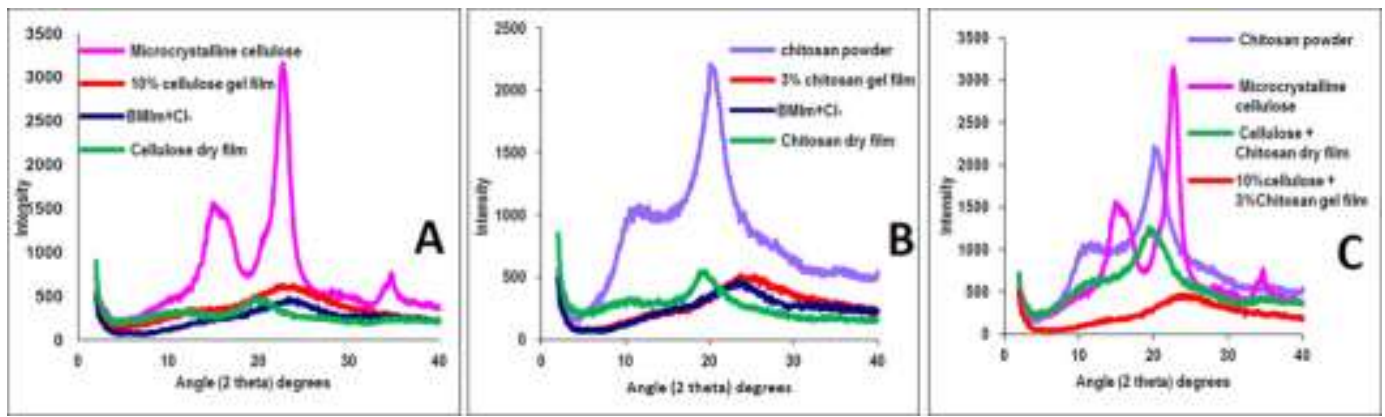

Figure 1 XRD spectra of microcrystalline CEL, CS powder, regenerated CEL, CS and $[C E L+C S]$ films.

Recently, there have been some reports on toxicity of ILs. However, the IL used in this work, $\left[\mathrm{BMIm}{ }^{+} \mathrm{Cl}^{-}\right]$, is relatively nontoxic compared to other ILs (its EC-50 and $\mathrm{LD}_{50}$ values are $897.47 \mathrm{ppm}$ and $550 \mathrm{mg} / \mathrm{kg}$, respectively [48]). Nevertheless, it is desirable to completely remove the IL from regenerated polysaccharide films to ensure the films are biocompatible. Since $\left[\mathrm{BMIm}^{+} \mathrm{Cl}^{-}\right]$is totally miscible with water (the logP, its octanol-water partition coefficient, is - 2.4 [49]), it was removed from the Gel Films by washing the films with water. Washing water ( $2 \mathrm{~L}$ for a composite film of about $10 \mathrm{~cm} \times 10 \mathrm{~cm}$ ) was repeatedly replaced with fresh water every $24 \mathrm{hrs}$ until it was confirmed that IL was not detected in the washed water (by monitoring UV absorption of the IL at $290 \mathrm{~nm}$ ). It was found that after washing for 72 hours, no IL was detected in the washing water by UV measurements. Since the limit of detection of the spectrophotometer used in this work was estimated to be about $3 \times 10^{-5} \mathrm{AU}$, and the molar absorptivity of $\left[\mathrm{BMIm}^{+} \mathrm{Cl}^{-}\right]$at $290 \mathrm{~nm}$ is 2.6 $\mathrm{M}^{-1} \mathrm{~cm}^{-1}$, it is estimated that if any $\left[\mathrm{BMIm}^{+} \mathrm{Cl}^{-}\right]$remains, its concentration would be smaller than $2 \mu \mathrm{g} / \mathrm{mL}$ of the washed water and $2 \mu \mathrm{g} / \mathrm{g}$ of the composite film. Since this concentration is two orders of magnitude lower than the $\mathrm{LD}_{50}$ value of the $\left[\mathrm{BMIm}^{+} \mathrm{Cl}^{-}\right]$, if any IL remains in the composite films, it would not pose any harmful effect. UV-vis, FTIR and NIR techniques were used to: (1) confirm that when the composite films were washed with water, $\left[\mathrm{BMIm}{ }^{+} \mathrm{Cl}^{-}\right]$was removed from the films to a level not detectable by these techniques; and (2) determine chemical composition of composite materials. Shown in Figure $2 \mathrm{~A}$ is NIR spectrum of $\left[\mathrm{BMIm}^{+} \mathrm{Cl}^{-}\right]$. As illustrated, been granted for this version to appear in e-Publications@Marquette. Elsevier does not grant permission for this article to be further copied/distributed or hosted elsewhere without the express permission from Elsevier. 
overtone and combination bands of aliphatic $\mathrm{C}-\mathrm{H}$ groups of the [BMIm ${ }^{+} \mathrm{Cl}^{-}$] can be clearly observed at $1388 \mathrm{~nm}$ and $1720 \mathrm{~nm}$ [50]. Since these bands are specific for $\left[\mathrm{BMIm}^{+} \mathrm{Cl}^{-}\right]$, they can be used as indicators to determine if the IL is present. Also shown in Figure $2 \mathrm{~A}$ are NIR spectra of Gel Films of CEL, CS and [CEL+CS]. Spectra of these Gel Films are very similar to that of $\left[\mathrm{BMIm}^{+} \mathrm{Cl}^{-}\right]$because the IL was the main component of these films. As shown in Figure 2B, After washing with water to remove the $\mathrm{IL}$, and drying, Dried Films of onecomponent CEL and CS samples were found to exhibit NIR spectra drastically different from those of their Gel Films shown in Fig 2A (spectra of Dried Films are shown together with the spectrum of $\left[\mathrm{BMIm}{ }^{+} \mathrm{Cl}^{-}\right]$for reference). The fact that NIR spectra of the Dried Films (Fig 2B) exhibit none of the indicator bands specific for $\left[\mathrm{BMIm}{ }^{+} \mathrm{Cl}^{-}\right.$] clearly indicates that washing with water effectively removed the IL from the films to a level which is not detectable by NIR technique. Further confirmation of removal of the ionic liquid from the films can also be seen in Figure 2C which shows FT-IR spectra of the same samples shown in $2 \mathrm{~B}$, namely, $\left[\mathrm{BMIm}{ }^{+} \mathrm{Cl}^{-}\right]$and Dried Films of $\mathrm{CEL}$ and $\mathrm{CS}$. As illustrated, $\left[\mathrm{BMIm}{ }^{+} \mathrm{Cl}^{-}\right.$] exhibits several distinct bands at around $756 \mathrm{~cm}^{-1}, 1173 \mathrm{~cm}^{-1}, 1468 \mathrm{~cm}^{-1}$ and $1572 \mathrm{~cm}^{-1}$. These bands can be attributed to aromatic $\mathrm{C}-\mathrm{H}$ bending, $-\mathrm{C}=\mathrm{N}$ - stretching, aromatic $\mathrm{C}-\mathrm{H}$ in-plane bending and aromatic $\mathrm{C}=\mathrm{C}$ stretching, respectively $[51,52]$. Again, none of these bands were present in the spectra of both CEL and CS Dried Films indicating that by washing with water, $\left[\mathrm{BMIm}{ }^{+} \mathrm{Cl}^{-}\right]$was removed from the composite films to a level which is not detectable by FTIR method.

Journal of Hazardous Materials, Vol. 252-253 (May 2013): pg. 355-366. DOI. This article is @ Elsevier and permission has been granted for this version to appear in e-Publications@Marquette. Elsevier does not grant permission for this article to be further copied/distributed or hosted elsewhere without the express permission from Elsevier. 


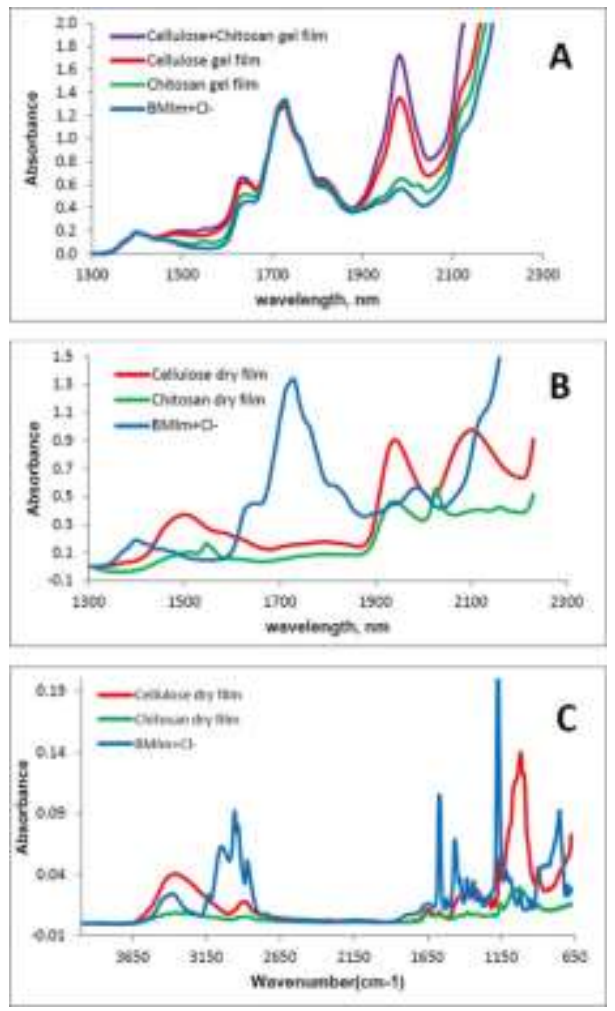

Figure 2 NIR spectra (A and B) and FTIR spectra (C) of: (A): $\left[\mathrm{BMIm}^{+} \mathrm{Cl}^{-}\right.$] solution (blue), CEL Gel Film (red), CS Gel Film (green) and [CEL+CS] Gel Film; (B) $\left[\mathrm{BMIm}^{+} \mathrm{Cl}^{-}\right]$solution (blue), CEL Dried Film (red) and CS Dried Film (green); and (C) $\left[\mathrm{BMIm}^{+} \mathrm{Cl}^{-}\right.$] solution (blue), CEL Dried Film (red) and CS Dried Film (green).

The IL used was recovered by distilling the washed aqueous solution (the IL remained because it is not volatile). The recovered $\left[\mathrm{BMIm}{ }^{+} \mathrm{Cl}^{-}\right]$was dried under vacuum at $70^{\circ} \mathrm{C}$ overnight before reuse. If needed, recovered $\left[\mathrm{BMIm}^{+} \mathrm{Cl}^{-}\right]$was decolored by heating at $70^{\circ} \mathrm{C}$ with activated charcoal. It was found that at least $88 \%$ of $\left[\mathrm{BMIm}^{+} \mathrm{Cl}^{-}\right]$ was recovered for reuse. As such, the method developed here is recyclable because [BMIm $\left.{ }^{+} \mathrm{Cl}^{-}\right]$is the only solvent used in the preparation and it is recovered for reuse. FTIR and NIR results indicate that recovered $\left[\mathrm{BMIm}{ }^{+} \mathrm{Cl}^{-}\right]$is structurally the same as freshly prepared $\left[\mathrm{BMIm}{ }^{+} \mathrm{Cl}^{-}\right]$, and that composite materials prepared using recovered $\left[\mathrm{BMIm}^{+} \mathrm{Cl}^{-}\right]$were found spectroscopically to be the same as those prepared using freshly made $\left[\mathrm{BMIm}{ }^{+} \mathrm{Cl}^{-}\right]$.

It is important to point out that the method developed here is not only different but also superior to the method recently reported in which magnetic CEL-CS gel microspheres were prepared using 
$\left[\mathrm{BMIm}{ }^{+} \mathrm{Cl}^{-}\right]$as a solvent. This is because that method is not green (various chemicals including vacuum pump oil, Span 80, ethanol), not recyclable (used $\left[\mathrm{BMIm}{ }^{+} \mathrm{Cl}^{-}\right.$] is not recovered for reuse) and can only prepare microspheres [53,54]. Conversely, the method developed here is green and recyclable (the only chemical used is $\left[\mathrm{BMIm}^{+} \mathrm{Cl}^{-}\right]$ and at least $88 \%$ of it was recovered for reuse) and can produce $[C E L+C S]$ composite materials in various forms (e.g. thin films, microparticles) which make them particularly suited for various applications.

It is noteworthy to add that the cost of $\left[\mathrm{BMIm}^{+} \mathrm{Cl}^{-}\right]$is comparable to those of solvents traditionally used to dissolve CEL and CS (see, for example, prices quoted in Sigma-Aldrich catalog: USD105/50g of [BMIm ${ }^{+} \mathrm{Cl}^{-}$] compared to USD46/500 $\mathrm{mL}$ of acetic acid (for traditional dissolution of CS); USD225/100g of metylmorpholine and USD230/100g of dimethylthexysilyl chloride (for traditional dissolution of (CEL)). However, the method reported here is much more economical compared to other methods because $\left[\mathrm{BMIm}{ }^{+} \mathrm{Cl}^{-}\right]$used in the dissolution is not lost but rather recovered for reuse.

Analysis of the film materials by SEM reveals some interesting features about the texture and morphology of the materials. Shown in Figure 3 are surface (top three images) and cross section images (bottom three images) of regenerated one component CS film (left) and CEL film (right) as well as 50:50 CEL:CS composite film (middle images). As expected, both surface and cross section images clearly indicate that one-component CEL and CS are homogeneous. Chemically, the only difference between CS and CEL is the few $-\mathrm{NH}_{2}$ groups in the former. However, their structures, as recorded by the SEM, particularly the cross section images, are substantially different. Specifically, while CS seems to exhibit smooth structure, CEL arranges itself into fibrous structure with fibers having diameter of about $\sim 0.5-$ 1.0 micron. As expected, the 50:50 CEL:CS composite material is not only homogeneous but also its structure is similar to both CEL and CS.

Journal of Hazardous Materials, Vol. 252-253 (May 2013): pg. 355-366. DOI. This article is @ Elsevier and permission has been granted for this version to appear in e-Publications@Marquette. Elsevier does not grant permission for this article to be further copied/distributed or hosted elsewhere without the express permission from Elsevier. 
NOT THE PUBLISHED VERSION; this is the author's final, peer-reviewed manuscript. The published version may be accessed by following the link in the citation at the bottom of the page.
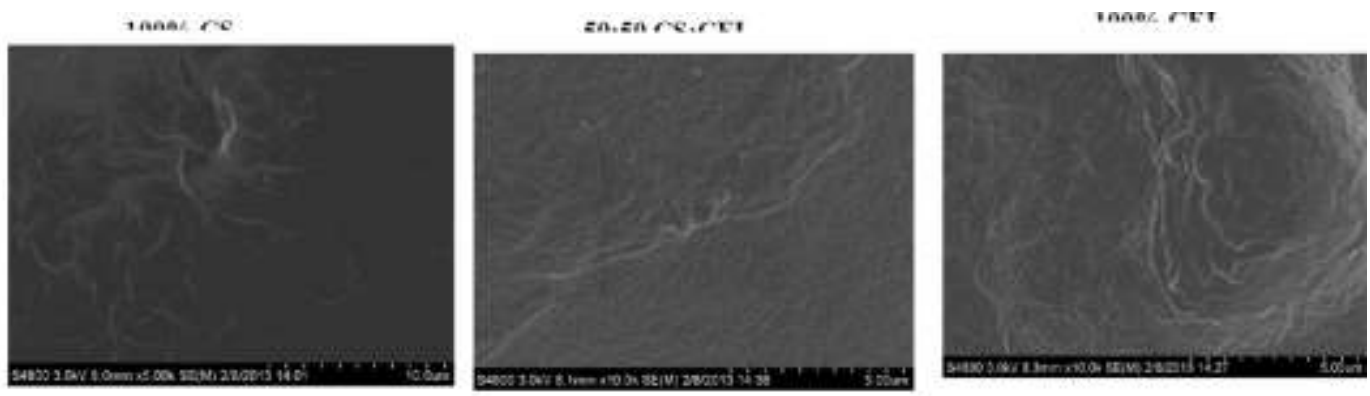

Cross Section Images
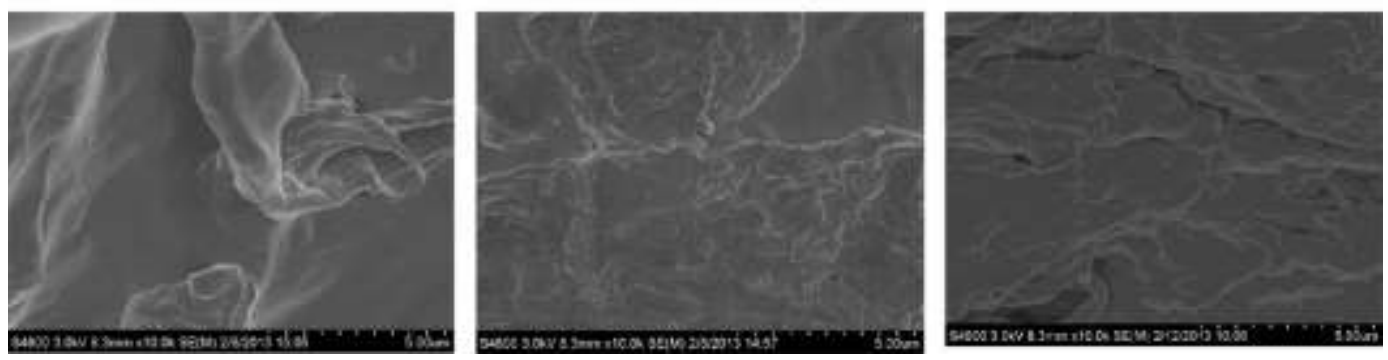

Figure 3 SEM images of surface (top three images) and cross section (bottom three images) of regenerated CS film (left), regenerated CEL film (right) and 50:50 $[C E L+C S]$ composite film (middle).

Chemically, the regeneration of both CEL and CS was confirmed by FTIR spectroscopy. As illustrated in figure 4A, the FTIR spectrum of microcrystalline CEL (blue spectrum) exhibits three pronounced bands at around $3400 \mathrm{~cm}^{-1}, 2850-2900 \mathrm{~cm}^{-1}$ and $890-1150 \mathrm{~cm}^{-1}$. These bands can be tentatively assigned to stretching vibrations of $\mathrm{O}-\mathrm{H}, \mathrm{C}-\mathrm{H}$ and -O- group, respectively [55- 57]. The fact that the Dried Film (red spectrum in 4A) also exhibits these three bands and is very similar to that of the microcrystalline CEL clearly indicates that CEL was completely regenerated by this synthetic method. Similarly, the FT-IR spectrum of a CS Dried Film (green spectrum in 4B) is similar to the FTIR spectrum of the CS powder (blue spectrum) from which it was made. These spectra display characteristic CS bands around $3400 \mathrm{~cm}^{-1}$ (O-H stretching vibrations), 3250-3350 $\mathrm{cm}^{-1}$ (symmetric and asymmetric $\mathrm{N}-\mathrm{H}$ stretching), $2850-2900 \mathrm{~cm}^{-1}$ (C-H stretching), $1657 \mathrm{~cm}^{-1}(\mathrm{C}=\mathrm{O}$, amide 1$), 1595 \mathrm{~cm}^{-1}(\mathrm{~N}-\mathrm{H}$ deformation $), 1380 \mathrm{~cm}^{-1}$ $\left(\mathrm{CH}_{3}\right.$ symmetrical deformation), $1319 \mathrm{~cm}^{-1}$ (C-N stretching, amide III) and $890-1150 \mathrm{~cm}^{-1}$ (ether bonding) [55-57]. These results indicate that both CEL and CS were successfully regenerated by the synthetic method developed here without any chemical transformation. 
NOT THE PUBLISHED VERSION; this is the author's final, peer-reviewed manuscript. The published version may be accessed by following the link in the citation at the bottom of the page.
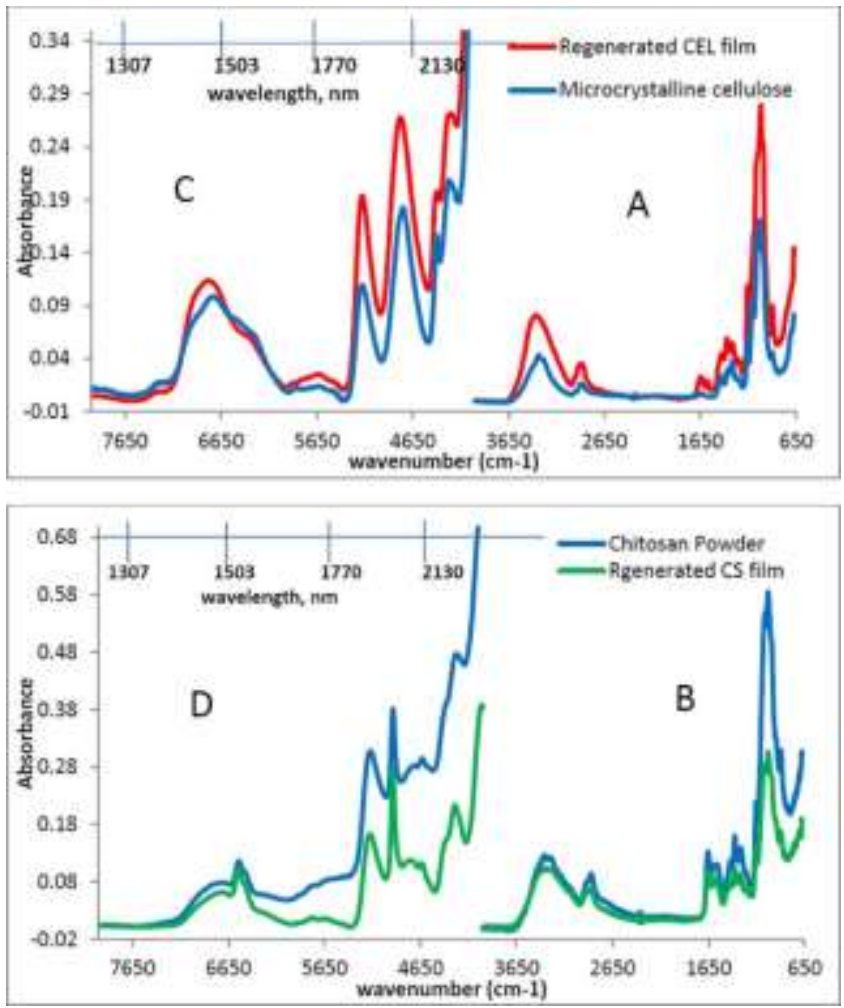

Figure 4 FTIR spectra ( $A$ and $B$ ) and NIR spectra ( $C$ and $D)$ of microcrystalline CEL (blue), regenerated CEL film (red), CS powder (blue) and regenerated CS film (green).

Results from NIR measurements further confirm regeneration of polysaccharide composite materials. Shown in Figure 4C are NIR spectra of microcrystalline CEL and regenerated CEL Dried Film (4C) and CS powder together with regenerated CS Dried Film (4D). As illustrated in 4C, both CEL microcrystalline and regenerated CEL film exhibit bands around 1492nm, 1938nm and around 2104nm. These can be attributed to the overtone and combination transition of the $\mathrm{OH}$ groups. Since CS also possesses the same $\mathrm{O}-\mathrm{H}$ groups in addition to $\mathrm{N}-\mathrm{H}_{2}$ group, NIR spectra of CS powder and film (4D) also have additional bands at around $1548 \mathrm{~nm}$ and $2028 \mathrm{~nm}$ which expectedly can be attributed to the $-\mathrm{NH}$ modes [57-60]. The similarity between the NIR spectra of starting polysaccharides and regenerated polysaccharide further confirms that CEL and CS were successfully regenerated by this preparation method.

${ }^{13} \mathrm{C}$ CP-MAS-NMR technique was then employed to further confirm structure of regenerated polysaccharide composite materials. Shown in Figure 5 are ${ }^{13} \mathrm{C}$ CP-MAS-NMR spectra obtained for

Journal of Hazardous Materials, Vol. 252-253 (May 2013): pg. 355-366. DOI. This article is (C) Elsevier and permission has been granted for this version to appear in e-Publications@Marquette. Elsevier does not grant permission for this article to be further copied/distributed or hosted elsewhere without the express permission from Elsevier. 
regenerated Dried Films of CEL (purple spectrum D), CS (red spectrum B) and 5:3 CEL:CS composite (light blue spectrum A) together CS powder (green spectrum C) amorphous cellulose powder (black spectrum E) and microcrystalline cellulose powder (dark blue spectrum F). Chemical shifts of all six samples are listed in Table 2. As expected, the spectra of CS powder, amorphous CEL powder and microcrystalline CEL powder agree with reported spectra [61-63]. The observed similarity between spectra and chemical shifts of corresponding carbons of regenerated dried films of CS and CEL to those of powder CS and powder of amorphous CEL is a clear indication that CEL and CS were successfully regenerated. Of particular interest is the fact that the spectrum of regenerated CEL film is similar to that of the amorphous CEL powder, and is distinctly different from that of microcrystalline powder. This can be clearly seen at band corresponding to $\mathrm{C}_{4}$ which is only a broad single band at $83.9 \mathrm{ppm}$, 84.4 ppm, respectively for regenerated CEL and amorphous CEL, but a doublet at $88.7 \mathrm{ppm}$ and $83.7 \mathrm{ppm}$ for crystalline CEL powder. These results seem to indicate that when microcrystalline CEL was dissolved by and regenerated from the IL, the regenerated CEL has relatively lower crystallinity than the microcrystalline CEL because IL disrupted inter- and intramolecular hydrogen bond network during the dissolution process. As a consequence, the regenerated CEL adapts an amorphous structure. These results not only confirm conclusion based on XRD results presented in previous section but also are in agreement with other previous studies [61-63]. CEL has relatively different chemical shifts compared to those of CS, particularly C2 and C6; i.e., in CEL, a single C6 band is at 62.0 ppm, C2 is together with C3 and C5 in a large band at $74.1 \mathrm{ppm}$ whereas in CS, C2 and C6 are together in a band at around $61.0 \mathrm{ppm}$, and the large band at $75.4 \mathrm{ppm}$ is due only to $\mathrm{C} 3$ and $\mathrm{C} 5$. Since these bands can be resolved into individual bands corresponding to C2, C3, C5 and C6 for each CEL and CS component of composite materials, it is possible to determine concentration of each polysaccharide component in composite materials using the CP-MAS-NMR technique. Of particular interest is the presence of the band corresponding to carbon of $\mathrm{CH}_{3}$ group in CS and CEL:CS composite material (but not in CEL) at around $22.7 \mathrm{ppm}$. This band can be attributed to remaining acyl groups of chitin, namely, chitosan obtained from commercial sources is not $100 \%$ but, as specified by the manufacturer in our case, is only $>75 \%$ converted 
from chitin. In fact, by accumulating spectra for longer time, this $\mathrm{CH}_{3}$ band can be clearly observed, and it can be used, together with FTIR method to determine exact degree of deacetylation of chitosan.

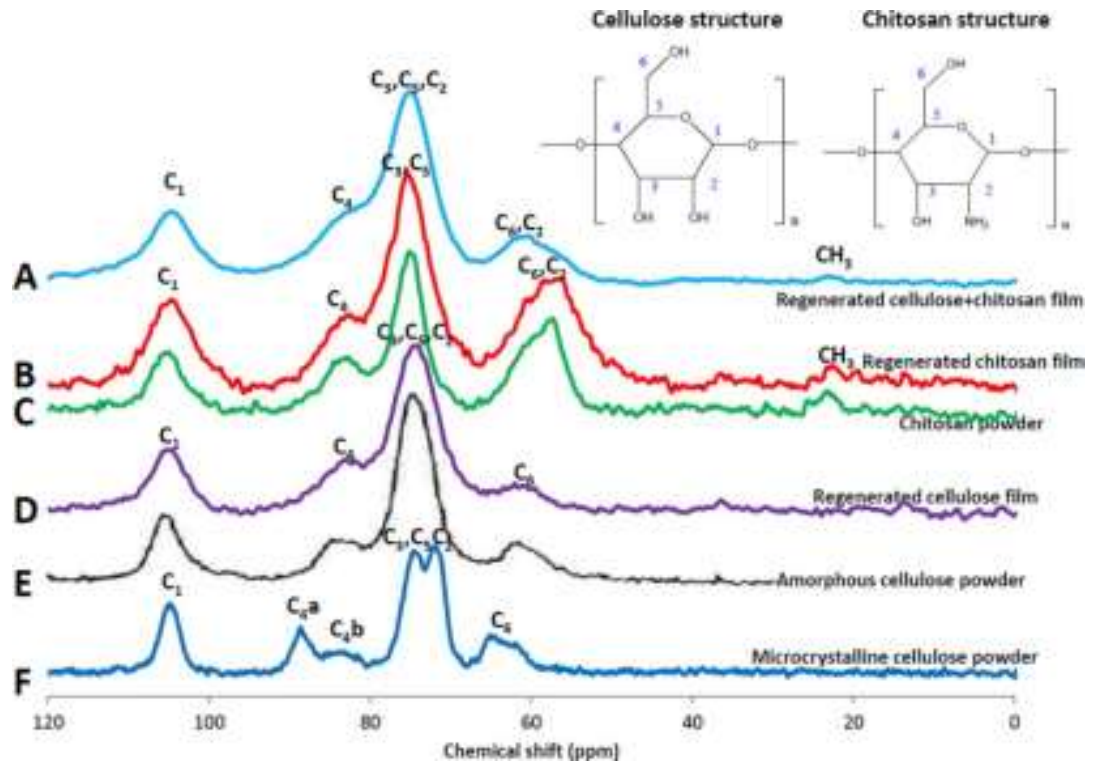

Figure $5{ }^{13} \mathrm{C}$ CP MAS NMR spectra of chitosan powder (C), amorphous CEL powder $(E)$, microcrystalline CEL powder $(F)$, regenerated CEL film (D), regenerated CS film (B) and $[\mathrm{CEL}+\mathrm{Cs}]$ composite films (A).

Table 2

\begin{tabular}{|c|c|c|c|c|c|c|c|}
\hline & \multicolumn{7}{|c|}{ Caitsoe chomicaf shifts (ppii) } \\
\hline & $G_{1}$ & $\mathrm{G}_{1}$ & Q & 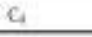 & $\Leftrightarrow$ & $C_{9}$ & $\mathrm{CH}_{3}$ \\
\hline Restenerated criltubse film & 104.6 & 241 & 741 & 83.9 & 741. & 620 & \\
\hline Arocphous oflitiose pander & 105.7 & 748 & 748 & 844 & 748 & 630 & \\
\hline Micrucystaliae cellulose powder & 1049 & 22. & 746 & $\$ 3,2,88.7$ & 746 & $647,62.3$ & \\
\hline Regenecated dutionan fitm & 19.7 & 610 & 754 & 836 & 75.4 & 610 & 227 \\
\hline Chitos.an powder & 104.9 & 60.1 & 747 & 340 & 747 & 601 & $2 n .4$ \\
\hline Regenerated cellukoe t ahitos an film & 1045 & 56.4 & 755 & $85 ; 9$ & 73.5 & 615 & 23.0 \\
\hline
\end{tabular}

\subsection{Properties of $[C E L+C S]$ Composites}

As described above, mechanical strength of CS is so poor that practically it cannot be used by itself for applications based on its unique properties. Measurements were made to determine tensile strength of pure CS film and (CS+CEL) composite films with different CEL concentrations in order to determine if by adding CEL into CS, the $[C E L+C S]$ composite material would have adequate mechanical strength for practical applications. Results obtained, shown in Fig 6A, clearly indicate that adding CEL into CS substantially increase its 
tensile strength. For example, up to $5 \mathrm{X}$ increase in tensile strength can be achieved by adding $80 \%$ of CEL into CS, and that the tensile strength of the composite material can be adjusted by adding judicious amount of CEL. More importantly, the tensile strengths of [CS+CEL] composite materials are comparable with those of existing CS materials including those prepared by either grafting or copolymerization with other chemicals [64-69].
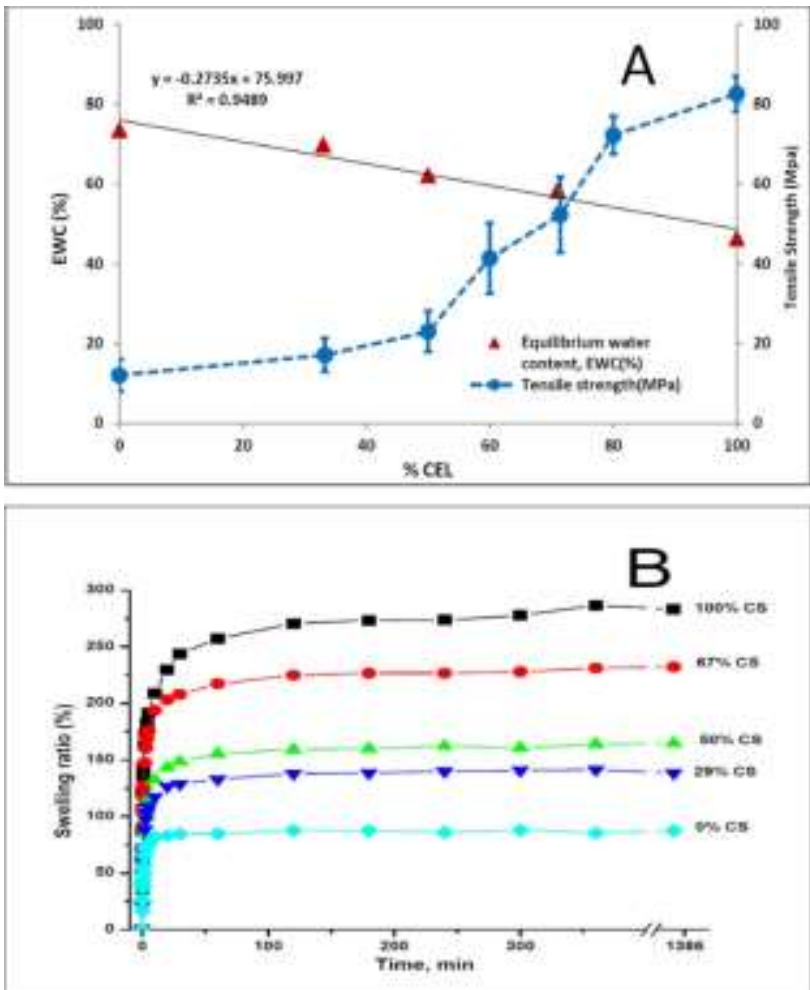

Figure 6 (A) Plot of tensile strength and equilibrium water content (EWC\%) as a function of CEL concentration and (B) swelling kinetics of different [CEL+CS] composite films.

As described above, CS has relatively poor mechanical strength because it undergoes swelling in water. Adding CEL into CS was found to improve mechanical strength of the composite. However, since the [CEL+CS] composite still swell in water, it is important to investigate the swelling of [CEL+CS] composites with different compositions in order to determine the optimal CEL/CS ratio which, in spite of swelling, can still provide a composite with adequate mechanical strength for its utilization. Accordingly, kinetics of swelling of [CEL+CS] composites with different compositions ranging from $0 \%$ to $100 \%$ CS were 
measured and results obtained are shown in Figure 6B which plot swelling ratio ( $\mathrm{S} \%$ ) as a function of time. As illustrated, for all composites, the water swelling occurred rapidly, reaching equilibrium in water uptake at about $120 \mathrm{~min}$. As expected, the swelling ratio was found to be proportional to the relative concentration of CS in the material with $100 \%$ CEL having the lowest value of $80 \%$ and $100 \%$ CS with the highest value of $270 \%$. Values for other composites are between these two values. More quantitative assessment can be obtained from equilibrium water content (EWC(\%) values. EWC \% and tensile strength values for [CEL+CS] composites with different compositions from 0 to $100 \%$ CS are listed in Table 1 and plotted together, as a function of CEL in the composites (Figure 6A). It is evident from the figure that the relationship between the tensile strength with CEL concentration is opposite to that of the swelling, namely, increasing CEL concentration leads to the increase in the tensile strength and the decrease in the swelling. However, the relative increase in the tensile strength is much larger than the decrease in the swelling. For example, tensile strength of $100 \% \mathrm{CEL}$ is 82.6 MPa which is $588 \%$ higher than that of $0 \% \mathrm{CEL}$ (12.0 MPa) whereas its EWC\% value of $46.4 \%$ is only $58 \%$ lower than the value for $73.6 \%$ for $0 \%$ CEL. This finding is particularly important because it clearly indicates that mechanical strength of the composite can be substantially strengthened by adding only relatively small amount of CEL. The composite still can retain its unique properties because the concentration of CEL added is so small to have any pronounced effect on the unique properties of the composites which are due solely to CS.

\section{Table 1}

Tensile strength and swelling parameters for [CEL + CS] composites.

\begin{tabular}{lll}
\hline$\%$ CS in [CEL + CS] composite & $\begin{array}{l}\text { Tensile } \\
\text { strength (MPa) }\end{array}$ & $\begin{array}{l}\text { Equilibrium water } \\
\text { content (EWC(\%)) }\end{array}$ \\
\hline 100 & 12.0 & 73.6 \\
67 & 17.1 & 69.9 \\
50 & 23 & 62.2 \\
40 & 41.4 & \\
29 & 52.3 & 58.5 \\
20 & 72.2 & \\
0 & 82.6 & 46.4 \\
\hline
\end{tabular}

Journal of Hazardous Materials, Vol. 252-253 (May 2013): pg. 355-366. DOI. This article is (C) Elsevier and permission has been granted for this version to appear in e-Publications@Marquette. Elsevier does not grant permission for this article to be further copied/distributed or hosted elsewhere without the express permission from Elsevier. 
Taken together, results presented clearly indicate that we have successfully developed a novel, green and recyclable method to dissolve CEL and CS and to prepare biocompartible all polysaccharide composite materials containing CEL and CS. As anticipated, adding CEL to CS material substantially increases mechanical strength of the CSbased composite. It is expected that the [CEL+CS] composite may retain its unique properties including bactericide, fungicide, drug delivery as well as good adsorbent for pollutants and toxins (from CS). Initial evaluation of their ability to adsorb MC-LR is described in following section.

\subsection{Adsorption of Microcystin-LR by [CEL+CS] Composites}

Experiments were designed to determine: (1) if [CEL+CS] composite materials can adsorb MC; (2) if they can, mechanism of adsorption processes in terms of rate constants and adsorbed amounts at equilibrium; and (3) composite material which gives highest adsorption. These were accomplished by fitting kinetic data to both pseudo-first order and pseudo-second order models in order to determine appropriate reaction order for the adsorption processes based on $\mathrm{R}^{2}$ and MSC values [70-72].

For pseudo-first order:

$$
\ln \left(q_{e}-q_{t}\right)=\ln q_{e}-k_{1} t
$$

For pseudo-second order

$$
\frac{t}{q_{t}}=\frac{1}{\left(k_{2} q_{r}^{2}\right)}+\frac{t}{q_{e}}
$$

where $\mathrm{k}_{1}$ and $\mathrm{k}_{2}$ are pseudo-first order and pseudo-second order rate constant of sorption $(\mathrm{g} / \mathrm{mg} . \mathrm{min}), \mathrm{q}_{\mathrm{e}}$ is the amount of analyte adsorbed at equilibrium $(\mathrm{mg} / \mathrm{g}), \mathrm{q}_{\mathrm{t}}$ is the amount of analyte adsorbed at any time $\mathrm{t}(\mathrm{mg} / \mathrm{g})$.

Journal of Hazardous Materials, Vol. 252-253 (May 2013): pg. 355-366. DOI. This article is (C) Elsevier and permission has been granted for this version to appear in e-Publications@Marquette. Elsevier does not grant permission for this article to be further copied/distributed or hosted elsewhere without the express permission from Elsevier. 
If the initial adsorption rate $h$ is

$$
h=k_{2} q_{e}^{2}
$$

Then Eq 2 can be rearranged as

$$
\frac{t}{q_{t}}=\frac{1}{h}+\frac{1}{q_{e}} t
$$

A linear plot can be obtained by plotting $t / q_{t}$ against $t . q_{e}$ and $h$, can obtained from the slope and intercept; $k_{2}$ can be calculated from $h$ and $\mathrm{q}_{\mathrm{e}}$ according to Eq 3.

As described in experimental section, kinetics of adsorption of $\mathrm{MC}$ by composite materials were determined by measuring change (i.e., decrease) in absorbance at $238 \mathrm{~nm}$ as a function of time in a solution containing a composite film. From measured absorbances, the amount of adsorbed MC at time $t$ (i.e., $\mathrm{q}_{\mathrm{t}}$ ) can then be calculated. Shown in figure 7A is plot of $\mathrm{q}_{\mathrm{t}}$ as a function of time for six different $[C E L+C S]$ materials with different composition ranging from $0 \%$ to $67 \%$ CS. It is evident from this plot that increasing CS concentration in the composite material led to increase in amount of microcystin adsorbed at equilibrium. Detailed information on adsorption kinetics can be obtained by fitting the data to both pseudo-first order (eq 1) and pseudo-second order (eq 4) model. Listed in Table 3 are results obtained for [CEL+CS] composite materials with different composition ranging from $20 \%$ to $67 \%$ of $\mathrm{CS}$. It was found that $0 \%$ chitosan (i.e., $100 \%$ CEL) material does not adsorb MC, and adsorption by composite material with $<20 \%$ CS was too small to be measured. Typical linearized plots for pseudo- $1^{\text {st }}$ order and psedo- $2^{\text {nd }}$ order for two samples are shown in Figure 8. It is evident from the plots as well as from the fact that $R^{2}$ and model selection criteria (MSC) values in all cases are relatively higher for pseudo- $2^{\text {nd }}$ order than for pseudo- $1^{\text {st }}$ order indicating that adsorption process follows pseudo- $2^{\text {nd }}$ order model. Results obtained clearly show that CS composite materials can adsorb MC very well. Material without CS (i.e., 0\%CS or $100 \% \mathrm{CEL}$ ) does not adsorb MC at all (yellow curve in Figure 7A), and that up to $96 \mathrm{mg}$ of MC can be adsorbed per $\mathrm{g}$ of the composites. The adsorptivity was found to be dependent on the concentration of CS in

Journal of Hazardous Materials, Vol. 252-253 (May 2013): pg. 355-366. DOI. This article is @ Elsevier and permission has been granted for this version to appear in e-Publications@Marquette. Elsevier does not grant permission for this article to be further copied/distributed or hosted elsewhere without the express permission from Elsevier. 
the composite, namely, increasing concentration of CS leads to an increase in amount of adsorbed MC. For example, increase of CS concentration from $20 \%$ to $67 \%$ led to $128 \%$ increase in the amount of adsorbed MC. This is as expected because adsorption is due mainly to CS; CEL does not have any adsorption ability toward MC. The role of CEL in the composite is, as explained above, to strengthen mechanical properties of the material. Again there is a concern that CS had two opposite effects on the properties of the composites: namely, it is responsible for the adsorption of MC but it also undergoes swelling in water which leads to weakening structure of the composites. However, this should not be a problem because the increase in adsorption efficiency with the CS concentration is much larger than that of the swelling (i.e., EWC \%). Specifically, increase of CS concentration from $20 \%$ to $67 \%$ led to $128 \%$ increase in the amount of adsorbed MC but only $29.2 \%$ increase in swelling (from 54.1 to $69.9 \%$ ).
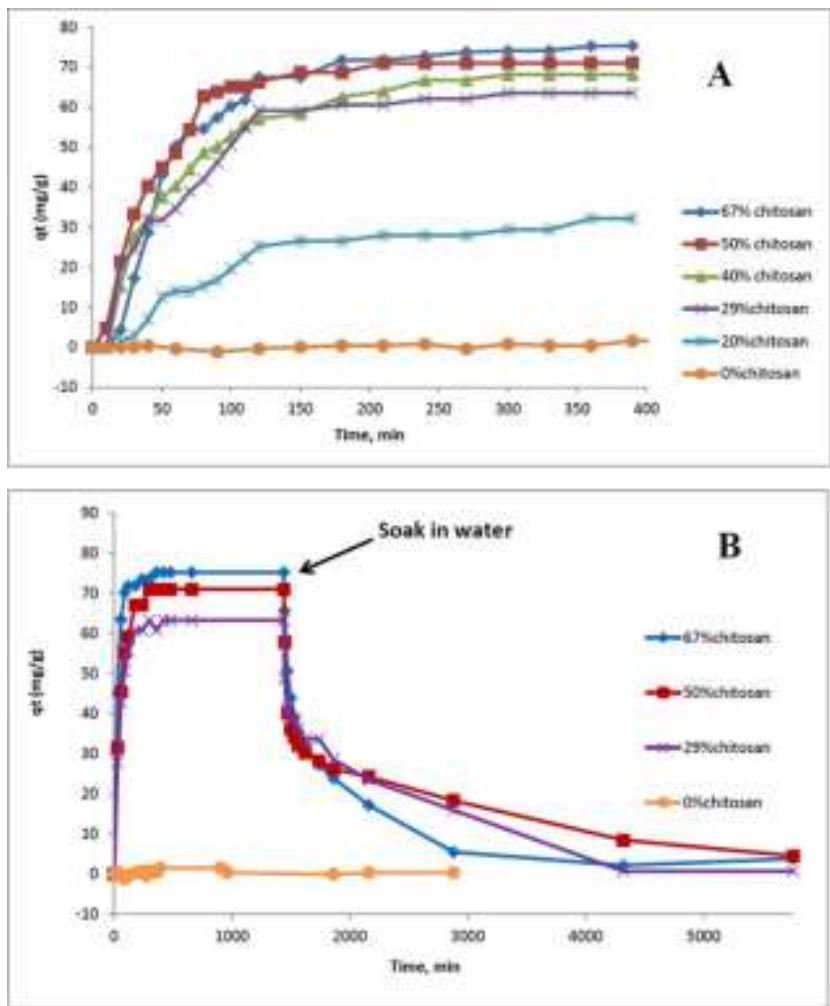

Figure 7 Plot of $q_{t}$ as a function of time for [CEL+CS] composite materials with different composition ranging from $20 \%$ to $67 \%$ CS. 
NOT THE PUBLISHED VERSION; this is the author's final, peer-reviewed manuscript. The published version may be accessed by following the link in the citation at the bottom of the page.
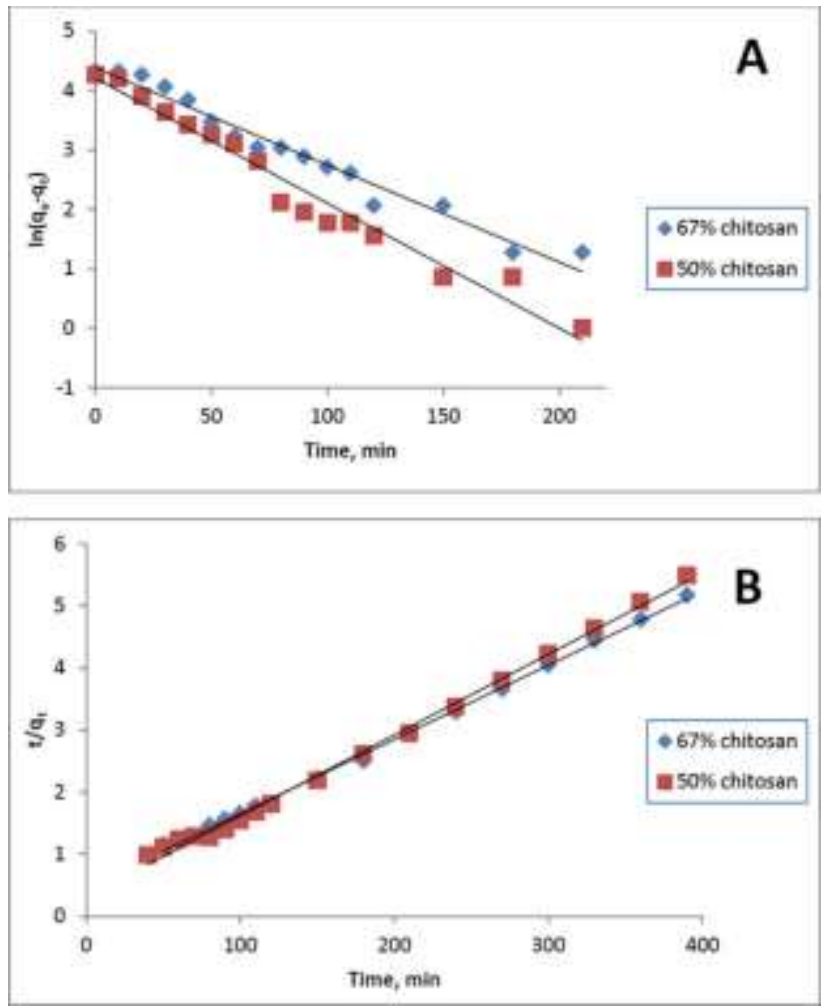

Figure 8 Typical linearized plots for (A) pseudo-first order and (B) pseudo-second order models for [CEL+CS] composite films containing $67 \%$ CS and $50 \%$ CS

Tathle 3

Parameters for micugostin-1R adsorption by [CE + CS] composite

\begin{tabular}{|c|c|c|c|c|c|c|c|c|c|}
\hline \multicolumn{2}{|c|}{ Conposite anuterial' } & \multicolumn{4}{|c|}{ Pseudo-first order } & \multicolumn{4}{|c|}{ Pseuda-second order } \\
\hline scharcsan & ¿cohiusose & o. (meig) & $\hat{z}_{1}($ miar-l') & $R^{2}$ & MST & Q. 3 aness & ho $10^{+}$(gimg win) & $\pi^{2}$ & MSSC \\
\hline 67 & J] & $94<8$ & $0.020+0.001$ & 0.9714 & 2.84 & $96+1$ & $1.5 \div 0.1$ & 0.9894 & 4.18 \\
\hline 50 & 50 & $72 \leq 1$ & $0.02 \pm 0.21$ & 09794 & 386 & $79 \pm 2$ & $5=3$ & 09963 & $5 . \%$ \\
\hline 40 & 60 & $52+1$ & $0010+0.007$ & 09370 & $2 \pi 2$ & $73+9$ & $3=1$ & 0,0050 & 566 \\
\hline 29 & 71 & $44=1$ & $0.01 \pm 0.02$ & 09419 & 2.73 & $71 \pm 2$ & $5=2$ & 09987 & $65 ?$ \\
\hline 20 & 80 & $31+5$ & $0.007+0.001$ & 0.7254 & 1.98 & $42+4$ & $19+0.3$ & 0.9922 & 5.00 \\
\hline
\end{tabular}

As described in the introduction, currently there are several absorbents available for removal of MC. Table 4 summarizes some of more popular adsorbents together with amount $(\mathrm{mg})$ of $\mathrm{MC}$ which can be removed per gram of the adsorbent. It is evidently clear from the table that the $[\mathrm{CS}+\mathrm{CEL}]$ composite materials reported here is much better adsorbent than all other materials. For example, one gram of the best reported adsorbent, $\mathrm{Fe}_{3} \mathrm{O}_{4} @ \mathrm{SiO}_{2}$ magnetic microspheres, can only adsorb $20 \mathrm{mg}$ of $\mathrm{MC}$ whereas $1 \mathrm{~g}$ of the [67\%CS+23\%CEL] material can remove up to $96 \mathrm{mg}$ or 4.8 times more MC. 
NOT THE PUBLISHED VERSION; this is the author's final, peer-reviewed manuscript. The published version may be accessed by following the link in the citation at the bottom of the page.

Table 4

List of Adsorbents for MC-LR.

\begin{tabular}{lll}
\hline Adsorber & $\begin{array}{c}\text { mg of adsorbed } \\
\text { MC-LR /g adsorber }\end{array}$ & Reference \\
\hline Iron Oxide Nanoparticles & 0.15 & {$[73]$} \\
$\mathrm{Fe}_{3} \mathrm{O}_{4} @$ copper silicate nanotube microspheres & 0.5 & {$[74]$} \\
Powdered activated carbon (PAC) & 0.75 & {$[2]$} \\
Natural clay particles & 4.6 & {$[75]$} \\
Carbon nanotubes & 5.9 & {$[76]$} \\
PAC/UF (membrane ultrafiltration) & 9.9 & {$[77]$} \\
Activated carbon fibers (ACF) & 17 & {$[78]$} \\
$\mathrm{Fe}_{3} \mathrm{O}_{4} @ \mathrm{SiO}_{2}$ magnetic microspheres & 20 & {$[79]$} \\
{$[\mathrm{CS}+\mathrm{CEL}]$ composite } & 96 & This work \\
\hline
\end{tabular}

Investigations were also carried out to determine if the $[C E L+C S]$ composites can be reused after they adsorb MC. Shown in Figure $7 \mathrm{~B}$ is plot of $\mathrm{q}_{\mathrm{t}}$ as a function of time during adsorption and desorption process for four different $[\mathrm{CEL}+\mathrm{CS}]$ materials with different compositions ranging from $0 \%$ to $67 \%$ CS (for clarity, plot is shown for only four composites). Specifically, the early portion of the plot (from $t=0$ to $t=24 \mathrm{hr}$ ) is the same as the plot of adsorption process shown in Figure 7A in which the composite materials adsorbed MC from solution. After $24 \mathrm{hrs}$, which was long after adsorption equilibrium had been reached, the composite materials were removed from the MC solutions and placed in pure water. This time, the MC previously adsorbed in the composite underwent desorption from the composites into the water (in both adsorption and desorption process, $\mathrm{q}_{\mathrm{t}}$ values, which is the amount of $M C$ in the composites at time $t$, were plotted. These values were calculated from measured concentrations of $M C$ in solution). As illustrated, for all [CEL+CS] composites whose compositions ranging from 0 to $67 \%$ CS, MC previously adsorbed in the composites was quantitatively removed. These results clearly indicate that [CEL+CS] composites are not only very efficient adsorbents for MC but also that the adsorbed MC can be quantitatively desorbed to enable the composites to be reused.

Measurements were also performed to determine if there are any changes in adsorption capability of composite materials when the materials are reused for the second time, i.e., composite materials in which previously adsorbed MC are desorbed. Shown in Figure 9 are plot of $\mathrm{q}_{\mathrm{t}}$ of adsorption of microcystin as a function of time by

Journal of Hazardous Materials, Vol. 252-253 (May 2013): pg. 355-366. DOI. This article is (C) Elsevier and permission has been granted for this version to appear in e-Publications@Marquette. Elsevier does not grant permission for this article to be further copied/distributed or hosted elsewhere without the express permission from Elsevier. 
[CS+CEL] composite films containing 67\%CS (A) and 50\% CS (B). For comparison, two curves are shown for each composite: Blue curves are for $1^{\text {st }}$ adsorption (i.e., by freshly prepared composites) and red curves are for $2^{\text {nd }}$ adsorption (i.e., adsorption by composites that were regenerated by desorbing MC previously adsorbed). As illustrated, for both composites, adsorption capacity of the composite materials remains the same after they were regenerated by desorbing $\mathrm{MC}$ previously adsorbed.

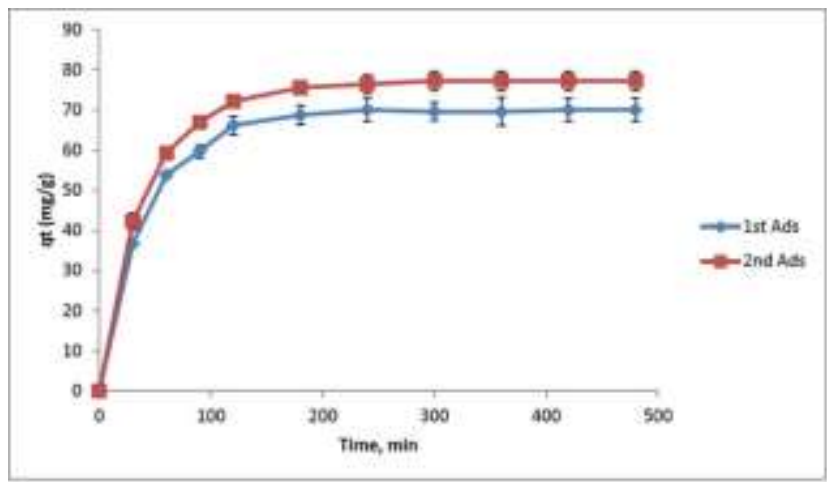

A

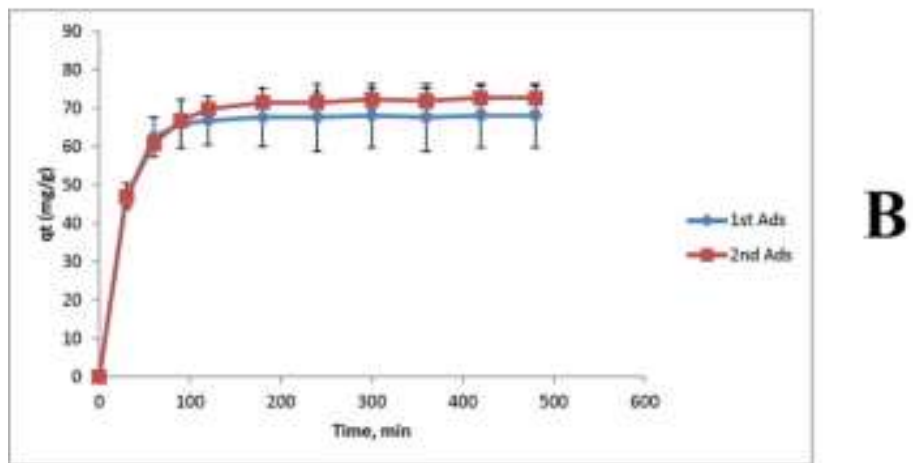

Figure 9 Plot of $\mathrm{q}_{\mathrm{t}}$ of adsorption of microcystin as a function of time by [CS+CEL] composite films containing $67 \%$ CS (A) and 50\% CS (B): Blue curves are for 1st adsorption (i.e., by freshly prepared films) and red curves are for 2 nd adsorption (i.e., adsorption by films that were regenerated by desorbing MC previously adsorbed).

\section{Conclusions}

In summary, we developed a simple and totally recyclable method to prepare biocompatible composites from CEL and CS. $\left[\mathrm{BMIm}{ }^{+} \mathrm{Cl}^{-}\right]$, an ionic liquid, was used as a solvent to dissolve and prepare the $[C E L+C S]$ composite materials. Since the IL was removed from the composites by washing them with water, and recovered by

Journal of Hazardous Materials, Vol. 252-253 (May 2013): pg. 355-366. DOI. This article is (C) Elsevier and permission has been granted for this version to appear in e-Publications@Marquette. Elsevier does not grant permission for this article to be further copied/distributed or hosted elsewhere without the express permission from Elsevier. 
distilling the washed solution, the method is totally recyclable. The $[\mathrm{CEL}+\mathrm{CS}]$ composites were found to have combined advantages of their components, namely superior mechanical stability (from CEL) and excellent adsorption capacity for MC-LR, a deadly toxin produced by cyanobacteria (from CS). Specifically, it was found that mechanical strength of the composites increased with CEL loading; e.g., up to $5 \mathrm{X}$ increase in tensile strength was achieved by adding $80 \%$ of CEL into CS. More importantly, the tensile strengths of the composites are comparable with those of existing CS-based materials including those prepared by either grafting or covalently attaching CS to man-made polymers. On the other hand, CS had two opposite effects on the properties of the composites: namely, it is responsible for the adsorption of $\mathrm{MC}$ but it also undergoes swelling in water which leads to weakening structure of the composites. However, this should not be a problem because the increase in adsorption efficiency with the CS concentration is much larger than that of the swelling (i.e., EWC \%). Additionally, not only the [CS+CEL] composite material reported here is biocompatible but also it is much better adsorbent than all other adsorbents currently available. For example, one gram of the best reported adsorbent, $\left.\mathrm{Fe}_{3}\right)_{4} @ \mathrm{SiO}_{2}$ magnetic microspheres, can only adsorb $20 \mathrm{mg}$ of MC whereas $1 \mathrm{~g}$ of the [67\%CS+23\%CEL] material can remove up to $96 \mathrm{mg}$ of $\mathrm{MC}$ (i.e., 4.8X more than the magnetic microspheres). More importantly, not only that the $\mathrm{MC}$ adsorbed on the composite materials can be quantitatively desorbed to enable the [CS+CEL] composite material to be reused, but that adsorption capability of the reused composites remain the same as those used for the first time. Preliminary results presented in this study are very encouraging and clearly indicate that higher adsorption efficiency can be obtained by judiciously modifying experimental conditions (e.g., replacing films of composite with microparticles to increase surface area, and $\mathrm{pH}$ of solution). These possibilities are subject of our current intense study.

\section{Highlights}

- A novel and recyclable synthetic method using an ionic liquid, a Green Solvent.

- Ecocomposite materials were synthesized from cellulose (CEL) and chitosan (CS). 
- Adding CEL into CS substantially increases tensile strength of the composite.

- The composite is much better adsorbent for cyanotoxins than other materials.

- The composite can be reused because adsorbed microcystin can be desorbed.

\section{Supplementary Material}

\section{Swelling behavior of composite films}

Swelling behavior of [CEL+CS] composite materials were determined using a procedure previously reported [SD-8]. Essentially, dried composite films of $2 \mathrm{~cm} \times 2 \mathrm{~m}$ were accurately weighed before being immersed in $100 \mathrm{~mL}$ of de-ionized water. At specific time intervals, the films were taken out from water, quickly blotted with a filter paper to remove water on the surface and then weighed immediately before being returned to the de-ionized water. The swelling ratio $(\mathrm{S} \%)$ of the composite films in de-ionized water was calculated from the following equation [SD-9 and 10] :

$$
S \%=\left(\frac{W_{s}-W_{d}}{W_{d}}\right) 100
$$

where $W_{s}$ and $W_{d}$ represent the weight of the swollen and dry films respectively.

The equilibrium water content (EWC) was calculated using the following equation [SD-9 and 10]:

$$
\operatorname{EWC}(\%)=\left(\frac{W_{e}-W_{d}}{W_{e}}\right) 100
$$

where $W_{e}$ and $W_{d}$ represent the weight of the swollen film at equilibrium and the dry film respectively.

Adsorption and Desorption Kinetics of Microcystin LR: For all adsorption measurements, duplicate samples (about $0.02 \mathrm{~g}$ ) of dry film $(C E L, C S$ or $[C E L+C S])$ were used. One piece was for the adsorption of microcystin and the other piece was used as the blank. The samples were washed thoroughly in water prior to the adsorption experiments

Journal of Hazardous Materials, Vol. 252-253 (May 2013): pg. 355-366. DOI. This article is @ Elsevier and permission has been granted for this version to appear in e-Publications@Marquette. Elsevier does not grant permission for this article to be further copied/distributed or hosted elsewhere without the express permission from Elsevier. 
to further ensure that $\left[\mathrm{BMIm}{ }^{+} \mathrm{Cl}^{-}\right]$was completely removed because absorption of any remaining IL may interfere with that of microcystin. To wash, the samples were placed in a thin cell fabricated from PTFE whose windows are covered by two PTFE meshes. The meshes ensured free circulation of water through the material during the washing process. The PTFE mould containing the samples was placed in a $2 \mathrm{~L}$ beaker containing water. The samples were stirred in water at room temperature for 24 hours. During this time, absorbance of the washing water was monitored at 214 and $287 \mathrm{~nm}$ to determine if there was any $\left[\mathrm{BMIm}{ }^{+} \mathrm{Cl}^{-}\right]$. The water was changed with fresh water every 4 hours.

After 24 hours, the composite was taken out of the water and placed into a spectrophotometric cell. The cell was stirred using a small magnetic spin bar during the measurement. To prevent disturbing of the sample by the spinning bar and to maximize circulation of the solution during measurement, the samples were sandwiched between two PTFE meshes. Specifically, a piece of PTFE mesh was placed at the bottom of the cell. The washed film sample was laid flat on top of the PTFE mesh. Another piece of PTFE mesh was placed on top of the sample and finally the small magnetic spin bar was placed on top of the second mesh. Exactly $2.70 \mathrm{~mL}$ of $3.7 \mathrm{mg} / \mathrm{L}$ microcystin aqueous solution was pipetted in to the cell. Measurements were carried out on a Perkin Elmer Lambda 35 UV/VIS spectrometer with the wavelength set to $238 \mathrm{~nm}$. The cells were returned to a magnetic stirrer after each measurement. Measurements were taken at 10 minute intervals during the first 2 hours and 20 minute intervals after 2 hours. Adsorption kinetics for each composite material were measured at least three times, and averaged values are reported.

To ensure that the adsorption of MC on to the composite materials reaches equilibrium, adsorption measurements were followed up to 24 hours. After 24 hours, the ability of the composite materials to release the MC for possible reuse was investigated. Specifically, a composite film was taken out of the MC solution at 24 hours and it was blotted with a filter paper to remove any excess MC solution from the composites. The film was then put back in a clean spectrophotometric cell equipped with the same arrangement as that used in the adsorption measurements, namely the film was sandwiched between two PTFE meshes and a magnetic spin bar was placed on top of the 
second PTFE mesh for stirring the sample. Exactly $2.7 \mathrm{~mL}$ of de-ionized water was pipetted in to the spectrophotometric cell. Release of MC from the film was followed by monitoring the increase in the UV absorbance of the solution at $238 \mathrm{~nm}$. Similar to the procedure that used in the adsorption measurements, samples were kept on a magnetic stirrer for continuous stirring with measurements being taken at specific time intervals.

\section{References}

[1] O. A. Battista and P. A. Smith, Microcrystalline Cellulose: The oldest polymer finds new industrial uses, Industrial and Eng. Chem. 54 (1962) 20 - 29.

[2] C. D. Tran and S. H. P. Lacerda, Determination of Binding Constants of Cyclodextrins in Room Temperature Ionic Liquids by Near-Infrared Spectrometry, Anal. Chem. 74 (2002) 53375341.

[3] C. Frez, G. Diebold, C. D. Tran S. Yu, Determination of Thermal Conductivities, Thermal Diffusivities, and Sound Speeds of Room Temperature Ionic Liquids by Transient Grating Technique, J. Chem. Eng. Data. 54 (2006) 1250-1255.

[4] R. P. Swatloski, S. Spear, J. D. Holbrey and R. D. Rogers, Dissolution of cellulose in ionic liquids, J. Am. Chem. Soc. 124 (2002) 4974-4975.

[5] M. S. Baptista, C. D. Tran and G. H. Gao, Near Infrared Detection of Flow Injection Analysis by Acousto-Optic Tunable Filter Based Spectrophotometry, Anal. Chem. 68 (1996) 971-976.

[6] C. D. Tran and X. Kong, Determination of Identity and Sequences of Tri- and Tetrapeptides by Near-Infrared Spectrometry, Anal. Biochem. 286 (2000) 67- 74.

[7] S. Duri, S. Majoni, J. M. Hossenlopp and C. D. Tran, Determination of Chemical Homogeneity of Fire Retardant Polymeric Nanocomposite Materials by Near-infrared Multispectral Imaging Microscopy, Anal. Lett. 43 (2010) 1780-1789.

[8] M. Ghaemy and M. Naseri, Synthesis of chitosan networks:

Swelling, drug release, and magnetically assisted BSA separation using $\mathrm{Fe}_{3} \mathrm{O}_{4}$ nanoparticles, Carbohydrate Pol. 90 (2012) $1265-1272$.

[9] S.J. Kim, S.R. Shin, N.G. Kim, S.I. Kim, Swelling behavior of semiinterpenetrating polymer network hydrogels based on chitosan

Journal of Hazardous Materials, Vol. 252-253 (May 2013): pg. 355-366. DOI. This article is @ Elsevier and permission has been granted for this version to appear in e-Publications@Marquette. Elsevier does not grant permission for this article to be further copied/distributed or hosted elsewhere without the express permission from Elsevier. 
NOT THE PUBLISHED VERSION; this is the author's final, peer-reviewed manuscript. The published version may be accessed by following the link in the citation at the bottom of the page.

and poly(acryl amide), J. Macromol. Sci. Part A: Pure and Applied Chemistry 42(2005) 1073-1083.

[10] E. Karadag, D. Saraydin, Swelling studies of super water retainer acrylamide/crotonic acid hydrogels crosslinked by trimethylolpropane triacrylate and 1,4-butanediol dimethacrylate, Polymer Bulletin 48(2002) 299 - 307.

Acknowledgment: Research reported in this publication was supported by the NIGMS of the NIH under Award number R15GM099033.

\section{Appendix A}

Supplementary data Supplementary data associated with this article can be found, in the online version, at http://www.ncbi.nlm.nih.gov/pmc/articles/PMC3660506/\#SD1

\section{Footnotes}

Publisher's Disclaimer: This is a PDF file of an unedited manuscript that has been accepted for publication. As a service to our customers we are providing this early version of the manuscript. The manuscript will undergo copyediting, typesetting, and review of the resulting proof before it is published in its final citable form. Please note that during the production process errors may be discovered which could affect the content, and all legal disclaimers that apply to the journal pertain.

\section{REFERENCES}

1. See for examples, Svircev Z, Krstic S, Malidinov-Mikov M, Baltic V, Vidovic M. Freshwater Cyanobacterial Blooms and Primary Liver Cancer Epidemiological Studies in Serbia. J. Environ. Sci. Health C. 2009;27:36-55. Giannuzzi L, Sedan D, Echenique R, Andrinolo D. An Acute Case of Intoxication with Cyanobacteria and Cyanotoxins in Recreational Water in Salto Grande Dam, Argentina. Mar. Drugs. 2011;9:2164-2175. Zegura B, Straser A, Filipic M. Genotoxicity and potential carcinogenicity of cyanobacterial toxins - a review. Mutation Res. 2011;727:16-41. [PubMed] Pearson L, Mihali T, Moffitt M, Kellmann R, Neilan B. On the Chemistry, Toxicology and Genetics of the Cyanobacterial Toxins, Microcystin, Nodularin, Saxitoxin and Cylindrospermopsin. Mar. Drugs. 2010;8:1650-1680.

Journal of Hazardous Materials, Vol. 252-253 (May 2013): pg. 355-366. DOI. This article is (C) Elsevier and permission has been granted for this version to appear in e-Publications@Marquette. Elsevier does not grant permission for this article to be further copied/distributed or hosted elsewhere without the express permission from Elsevier. 
2. Newcombe G, Nicholson B. Water Treatment options for Dissolved Cyanotoxins. J. Water Suppl. Res. Tech. 2004;534:227-239.

3. Westrick JA, Szlag DC. A Review of Cyanobacteria and Cyanotoxins Removal/Inactivation in Drinking Water Treatment. Anal. Bioanal. Chem. 2010;397:1705-1714.

4. Chen L, Dionysiou DD, O'Shea K. Complexation of Microcystins and Nodularin by Cyclodextrins in Aqueous Solution, a Potential Removal Strategy. Environ. Sci. Tech. 2011;45:2293-2300.

5. Finkenstadt VL, Millane RP. Crystal Structure of Valonia Cellulose $1 \beta$ Macromolecules. 1998;31:7776-7783.

6. Augustine AV, Hudson SM, Cuculo JA. Cellulose Sources and Exploitation. New York: Ellis Horwood; 1990.

7. Dawsey TR. Cellulosic Polymers, Blends and Composites. New York: Carl Hanser Verlag; 1994.

8. Kadowaka M, Mukarami J, Kaneko Y. A facile preparation of gel materials from a solution of cellulose in ionic liquid. Carbohydrate Res. 2008b;343:769-772.

9. Cai J, Liu Y, Zhang L. Dilute solution properties of cellulose in $\mathrm{LiOH} /$ urea aqueous system. J. Polym. Sci. B. Pol. Phys. 2006;44:3093-30105.

10. Fink HP, Weigel P, Purz HJ, Ganster J. Structure formation of regenerated cellulose materials from NMMO-solutions. Progress Polym. Sci. 2001;26:1473-1524.

11. Dai T, Tegos GP, Barkatovskaya M, Castano AP, Hamblin MR. Chitosan Acetate bandage as a topical antimicrobial dressing for infected burns. Anticrobial Agents Chemo. 2009;53:393-400.

12. Bordenave N, Grelier S, Coma V. Hydrophobization and Antimicrobial activity of chitosan and paper-based packaging materials. Biomacromolecules. 2010;11:88-96.

13. Rabea EI, Badawy MET, Stevens CV, Smagghe G, Steurbaut W. Chitosan as antimicrobial agent: Applications and mode of action. Biomacromolecules. 2003;4:1457-1465.

14. Altiok D, Altiok E, Tihminlioglu F. Physical, antibacterial and antioxidant properties of chitosan films incorporated with thyme oil for potential wound healing applications. J. Mater. Sci: Mater. Med. 2010;21:22272236.

15. Burkatovskaya M, Tegos GP, Swietlik E, Demidova TN, Castano AP, Hamblin MR. Use of chitosan bandage to prevent fatal infections developing from highly contaminated wounds in mice. Biomaterials. 2006;27:4157-4164.

16. Gustafson SB, Fulkerson P, Bildfell R, Aguilera L, Hazzard TM. Chitosan dressing provides hemostasis in swine femoral arterial injury model. Prehospital Emergency Care. 2007;11:172-178.

Journal of Hazardous Materials, Vol. 252-253 (May 2013): pg. 355-366. DOI. This article is (C) Elsevier and permission has been granted for this version to appear in e-Publications@Marquette. Elsevier does not grant permission for this article to be further copied/distributed or hosted elsewhere without the express permission from Elsevier. 
17. Pusateri AE, McCarthy SJ, Gregory KW, Harris RA, Cardenas L, McManus AT, Goodwin CW. Effect of a chitosan-based haemostatic dressing on blood loss and survival in a model of severe venous hemorrhage and hepatica injury in swine. J. Trauma Injury Infect. Crit. Care. 2003;54:177-182.

18. Keong LC, Halim AS. In vitro models in biocompatibility assessment for biomedical-grade chitosan derivatives in wound management. International J. Mol. Sci. 2009;10:1300-1313.

19. Kiyozumi T, Kanatani $Y$, Ishihara $M$, Saitoh D, Shimizu J, Yura $H$, Suzuki S, Okada Y, Kikuchi M. Medium (DMEM/F12)-containing chitosan hydrogel as adhesive and dressing in autologous skin grafts and accelerator in the healing process. J. Biomed. Mat. Res. B: Appl. Biomat. 2006;79B:129-136.

20. Rossi S, Sandri G, Ferrari F, Benferonic MC, Caramella C. Buccal delivery of acyclovir from films based on chitosan and polyacrylic acid. Pharm. Dev. Tech. 2003;8:199-208.

21. Jain D, Banerjee R. Comparison of ciprofloxacin hydrochloride-loaded protein, lipid, and chitosan nanoparticles for drug delivery. J. Biomed. Mat. Res. B Appl Biomater. 2008;86:105-112.

22. Varshosaz J, Tabbakhian M, Salmani Z. Designing of a thermosensitive chitosan/poloxamer in situ gel for ocular delivery of ciprofloxacin. Open Drug Delivery J. 2008;2:61-70.

23. Elmotasem $\mathrm{H}$. Chitosan-alginate blend films for the transdermal delivery of meloxicam. Asian J. Pharm. Sci. 2008;3:12-29.

24. Naficy S, Razal JM, Spinks GM, G. G. Wallace GG. Modulated release of dexamethasone from chitosan-carbon nanotube films. Sensors Attuators A. 2009;155:120-124.

25. Tirgar A, Golbabaei F, Hamedi J, Nourijelyani K, Shahtaheri SJ, Moosavi $\mathrm{SR}$. Removal of airborne hexavalent chromium mist using chitosan gel beads as a new control approach. Int. J. Environ. Sci. Tech. $2006 ; 3: 305-313$.

26. Nishiki M, Tojima T, Nishi N, Sakairi N. $\beta$-Cyclodextrin-linked chitosan beads: preparation and application to removal of bisphenol $A$ from water. Carbohydrate Lett. 2000;4:61-67.

27. Hassan MAA, Hui LS, Noor ZZ. Removal of boron from industrial wastewater by chitosan via chemical precipitation. J. Chem. Nat. Res. Eng. 2009;4:1-11.

28. Dhakal RP, Oshima T, Baba Y. Synthesis of unconventional materials using chitosan and crown ether for selective removal of precious metal ions. World. Acad. Sci. Eng. Tech. 2009;56:204-208.

29. Ngah WWS, Isa IM. Comparison study of copper ion adsorption on chitosan, Dowex A-1, and Zerolit 225. J. Appl. Pol. Sci. 1998;67:10671070.

Journal of Hazardous Materials, Vol. 252-253 (May 2013): pg. 355-366. DOI. This article is (C) Elsevier and permission has been granted for this version to appear in e-Publications@Marquette. Elsevier does not grant permission for this article to be further copied/distributed or hosted elsewhere without the express permission from Elsevier. 
30. Govindan VS. Effect of chitosan on harvesting of algal biomass from stabilization pond effluents. Asian Env. 1985;7:4.

31. Qiao J, Dong L, Hu Y. Removal of harmful algal blooms using activated fly ash-modified chitosan. Fres. Env. Bull. 2011;20:764-772.

32. Wang Y, Zhuo S, Yang Y, Li N. Application of chitosan in removing algae by dissolved air flotation. Adv. Mat. Res. 2012:347-353. (Pt. 4, Renewable and Sustainable Energy), 1911-1916.

33. Zou H, Pan G, Chen H, Yan Removal of cyanobacterial blooms in Taihu Lake using local soils. II. Effective removal of Microsystis aeruginosa using local soils and sediments modified by chitosan. Env. Pollution. 2006;141:201-205.

34. Pan G, Zou H, Chen $H$, Yuan X. Removal of harmful cyanobacterial blooms in Taihu Lake using local soils. III. Factors affecting the removal efficiency and an in situ field experiment using chitosan-modified local soils. Env. Pollution. 2006;141:206-212.

35. Yan Q, Yu Y, Feng W, Pan G, Chen H, Chen J, Yang B, Li X, Zhang X. Plankton community sucession in artificial systems subjected to cyanobacterial blooms removal using chitosan modified soils. Microb. Ecol. 2009;58:47-55.

36. Swatloski RP, Spear S, Holbrey JD, Rogers RD. Dissolution of cellulose in ionic liquids. J. Am. Chem. Soc. 2002;124:4974-4975.

37. El Seould OA, Koschella A, Fidale LC, Dorn S, Heinze T. Applications of ionic liquids in carbohydrate chemistry: A Window of opportunities. Biomacromolecules. 2007;8:2629-2647.

38. Pinkert A, Marsh KN, Pang S, Staiger MP. Ionic liquids and their interaction with cellulose. Chem. Rev. 2009;109:6712-6728.

39. Tran CD, Lacerda SHP. Determination of Binding Constants of Cyclodextrins in Room Temperature Ionic Liquids by Near-Infrared Spectrometry. Anal. Chem. 2002;74:5337-5341.

40. See, for examples, Han X, Armstrong DW. Ionic Liquids in Separations. Acc. Chem. Res. 2007;40:1079-1086. Tran CD. Ionic Liquids Applications: Pharmaceutical, Therapeutics and Biotechnology. ACS Symposium Series. 2010;1038:35-54. Welton T. Room-Temperature Ionic Liquids. Solvents for Synthesis and Catalysis. Chem. Rev. 1999;99:2071-2083. Wasserscheid P, Welton T. Ionic Liquids in Synthesis. Weinheim, Germany: Wiley- $\mathrm{VCH} ; 2003$. Tran CD. Ionic liquids for and by Analytical Chemistry. Anal. Lett. 2007;40:24472464.

41. Battista OA, Smith PA. Microcrystalline Cellulose: The oldest polymer finds new industrial uses. Industrial and Eng. Chem. 1962;54:20-29.

42. Tran CD, Lacerda SHP. Determination of Binding Constants of Cyclodextrins in Room Temperature Ionic Liquids by Near-Infrared Spectrometry. Anal. Chem. 2002;74:5337-5341.

Journal of Hazardous Materials, Vol. 252-253 (May 2013): pg. 355-366. DOI. This article is (C) Elsevier and permission has been granted for this version to appear in e-Publications@Marquette. Elsevier does not grant permission for this article to be further copied/distributed or hosted elsewhere without the express permission from Elsevier. 
NOT THE PUBLISHED VERSION; this is the author's final, peer-reviewed manuscript. The published version may be

accessed by following the link in the citation at the bottom of the page.

43. Frez C, Diebold G, Tran CD, Yu S. Determination of Thermal Conductivities, Thermal Diffusivities, and Sound Speeds of Room Temperature Ionic Liquids by Transient Grating Technique. J. Chem. Eng. Data. 2006;54:1250-1255.

44. Swatloski RP, Spear S, Holbrey JD, Rogers RD. Dissolution of cellulose in ionic liquids. J. Am. Chem. Soc. 2002;124:4974-4975.

45. Baptista MS, Tran CD, Gao GH. Near Infrared Detection of Flow Injection Analysis by Acousto-Optic Tunable Filter Based Spectrophotometry. Anal. Chem. 1996;68:971-976.

46. Tran CD, Kong X. Determination of Identity and Sequences of Tri- and Tetrapeptides by Near-Infrared Spectrometry. Anal. Biochem. 2000;286:67-74.

47. Duri S, Majoni S, Hossenlopp JM, Tran CD. Determination of Chemical Homogeneity of Fire Retardant Polymeric Nanocomposite Materials by Near-infrared Multispectral Imaging Microscopy. Anal. Lett. 2010;43:1780-1789.

48. Docherty KM, Kulpa CF. Toxicity and antimicrobial activity of imidazolium and pyridinium ionic liquids. Green Chem. 2005;7:185-189.

49. Ropel L, Belveze LS, K. Aki SNV, Stadtherr MA, Brennecke JF. Octanolwater partition coefficients of imidazolium-based ionic liquids. Green Chem. 2005;7:83.

50. Tran CD, Lacerda SP, Oliveira D. Absorption of Water by RoomTemperature Ionic Liquids: Affect of Anions on Concentration and States of Water. Appl. Spectrosc. 2003;57:152-157.

51. Jeon $Y$, Sung J, Seo C, Lim H, Cheong H, Kang M, Moon B, Ouchi Y, Kim D. Structures of ionic liquids with different anions studied by Infrared vibration spectroscopy. J. Phys. Chem. B. 2008;112:4735-4740.

52. Seethalakshmi K, Jasmine Vasantha Rani E, Padmavathy R, Radha N. FTIR spectral analysis of imidazolium chloride. Int. J. Cur. Res. Rev. 2012;4:31-36.

53. Liu Z, Wang H, Li B, Liu C, Jiang Y, Yu G, Mu X. Biocompatible magnetic cellulose-chitosan hybrid gel microspheres reconstituted from ionic liquids for enzyme immobilization. J. Mater. Chem. 2012;22:1508515091.

54. Liu Z, Wang H, Liu C, Jiang Y, Yu G, Mu X, Wang X. Magnetic cellulosechitosan hydrogels prepared from ionic liquids as reusable adsorbents for removal of heavy metal ions. Chem. Comm. 2012;48:7530-7532.

55. Da Roz AL, Leite FL, Pereiro LV, Nascente PAP, Zucolotto V, Oliveira ON, Carvalho AJF. Adsorption of chitosan on spin-coated cellulose films. Carbohydrate Pol. 2010;80:65-70.

56. Dreve S, Kacso I, Bratu I, Indrea E. Chitosan-based delivery systems for diclofenac delivery: Preparation and characterization. J. Phys.: Conference Series. 2009;182:1-4.

Journal of Hazardous Materials, Vol. 252-253 (May 2013): pg. 355-366. DOI. This article is (C) Elsevier and permission has been granted for this version to appear in e-Publications@Marquette. Elsevier does not grant permission for this article to be further copied/distributed or hosted elsewhere without the express permission from Elsevier. 
57. Burns DA, Ciurczak EW. Handbook of Near-Infrared Analysis. New York: Marcell Dekker; 1992.

58. Ellis JW. Infra-red absorption by the $\mathrm{N}-\mathrm{H}$ bond II in aryl, alkyl and arylalkyl amines. J. Am. Chem. Soc. 1928;50:685-695.

59. Baptista MS, Tran CD, Gao GH. Near Infrared Detection of Flow Injection Analysis by Acousto-Optic Tunable Filter Based Spectrophotometry. Anal. Chem. 1996;68:971-976.

60. Tran CD, Kong X. Determination of Identity and Sequences of Tri- and Tetrapeptides by Near-Infrared Spectrometry. Anal. Biochem. $2000 ; 286: 67-74$.

61. Zhang L, Ruan D, Gao S. Dissolution and regeneration of cellulose in $\mathrm{NaOH} /$ Thiourea aqueous solution. J. Pol. Sci: Part B: Polymer Physics. 2002;40:1521-1529.

62. Mori T, Chikayama E, Tsuboi Y, Ishida N, Shisa N, Noritake Y, Moriya S, Kikuchi J. Exploring the conformationa; space of amorphous cellulose using NMR chemical shifts. Carbohydrate Polymers. 2012;90:11971203.

63. Sebe G, Ham-Pichavant F, Ibarboure E, Koffi ALC, Tingaut P. Supramolecular structure characterization of cellulose II nanowhiskers producued by acid hydrolysis of cellulose I substrates.

Biomacromolecules. 2012;13:570-578.

64. Kiuchi $\mathrm{H}$, Kai W, Inoue $\mathrm{Y}$. Preparation and characterization of poly(ethylene glycol) crosslinked chitosan films. J.Appl. Polym. Sci. 2008;107:3823-3830.

65. Khamhan S, Baimark Y, Chaichanadee S, Phinyocheep P, Kittipoom SW. Water Vapor Permeability and Mechanical Properties of Biodegradable Chitosan/Methoxy Poly(ethylene glycol)-b-Poly( $\varepsilon$-caprolactone) Nanocomposite Films. Internt'l. J. Polym. Anal. Charact. 2008;13:224231.

66. Alam R, Khan AM, Khan AR, Ghoshal S, Mondal MIH. Study on the Physico-mechanical Properties of Photo-cured Chitosan Films with Oligomer and Acrylate Monomer. J. Polym. Env. 2008;16:213-219.

67. Liang S, Liu L, Huang Q, Yam LK. Preparation of single or doublenetwork chitosan/poly(vinyl alcohol) gel films through selectively cross-linking method. Carbohydrate Polym. 2009;77:718-724.

68. Khan MA, Alam R, Noor F, Khan RA, Md. Rahman A. Modification and Characterization of Chitosan Films Using 3-trimethoxysilylpropyl methacrylate. J. Macrom. Sci., Part A: Pure and Applied Chemistry. 2009;46:751-758.

69. Radhakumary C, Prabha DN, Reghunadhan CPN, Mathew S.

Chitosancomb- graft-polyethylene glycol monomethacrylate-Synthesis, characterization, and evaluation as a biomaterial for hemodialysis applications. J. Appl. Polym. Sci. 2009;114:2873-2886.

Journal of Hazardous Materials, Vol. 252-253 (May 2013): pg. 355-366. DOI. This article is (C) Elsevier and permission has been granted for this version to appear in e-Publications@Marquette. Elsevier does not grant permission for this article to be further copied/distributed or hosted elsewhere without the express permission from Elsevier. 
70. Ho YS, McKay G. The kinetics of sorption of divalent metal ions onto sphagnum moss peat. Wat. Res. 2000;34:735-742.

71. Kumar KV, Sivanesan S. Pseudo second order kinetics and pseudo isotherms for malachite green onto activated carbon: Comparison of linear and non- linear regression methods. J. Hazardous Mat. B. 2006;136:721-726.

72. Li Q, Sun L, Zhang Y, Qian Y, Zhai J. Characteristics of equilibrium, kinetics studies for adsorption of $\mathrm{Hg}$ (II) and CRVI) by polyaniline/humic acid composite. Desalination. 2011;266:188-194.

73. Gao Y, Gao N, Gu J, Shen Y. S Wang, Adsorption of Microcystin-LR from Water with Iron Oxide Nanoparticles. Water Environ. Res. 2012;84:562-568.

74. Chen H, Lu X, Deng C, Yan X. Facile synthesis of uniform microsphere composed of magnetite core and copper silicate nanotube shell for removal of Microcystins in water. J. Phys. Chem. C. 2009;113:2106873.

75. Morris RJ, Williams DE, Luu HA, Holmes CFB, Andersen RJ, Calvert SE. The adsorption of microcystin-LR by natural clay particles. Toxicon. $2000 ; 38: 303-308$.

76. Yan $\mathrm{H}$, Gong A, He H, Zhou J, Wei Y. Adsorption of microcystins by carbon nanotubes. Chemosphere. 2006;62:142-148.

77. Lee J, Walker $\mathrm{H}$. Effects of process variables and natural organic matter on removal of microcystin-LR by PAC-UF. Environ. Sci. Technol. 2006;40:7336-7342.

78. Pyo D, Moon D. Adsorption of Microcystin LR by activated carbon fibers. Bull. Korean Chem. Soc. 2005;26:2089-92.

79. Deng YH, Qi DW, Deng C, Zhang XM, Zhao DY. Superparamagnetic highmagnetization microspheres with an $\mathrm{Fe}_{3} \mathrm{O}_{4} @ \mathrm{SiO}_{2}$ core and perpendicularly aligned mesoporous $\mathrm{SiO} 2$ shell for removal of Microcystins. Am. Chem. Soc. 2008;130:28-29.

Journal of Hazardous Materials, Vol. 252-253 (May 2013): pg. 355-366. DOI. This article is @ Elsevier and permission has been granted for this version to appear in e-Publications@Marquette. Elsevier does not grant permission for this article to be further copied/distributed or hosted elsewhere without the express permission from Elsevier. 